\title{
Investigation of surface structure, electrokinetic and stability properties of highly dispersed $\mathrm{Ho}_{2} \mathrm{O}_{3}-\mathrm{Yb}_{2} \mathrm{O}_{3} / \mathrm{SiO}_{2}$ nanocomposites
}

\section{Iryna Sulym $^{1 *}$, Małgorzata Wiśniewska ${ }^{2}$, Liudmyla Storozhuk ${ }^{1,3,4}$, Konrad Terpilowski ${ }^{2}$} Dariusz Sternik $^{2}$, Mykola Borysenko ${ }^{1}$, Anna Derylo-Marczewska ${ }^{2}$

${ }^{1}$ Chuiko Institute of Surface Chemistry, NASU, 17 General Naumov Str., 03164 Kyiv, Ukraine

${ }^{2}$ Institute of Chemical Sciences, Maria Curie-Sklodowska University in Lublin, M.C. Sklodowska Sq.3, 20031 Lublin, Poland

${ }^{3}$ Department of Physics \& Astronomy, University College London, Gower Street, London WC1E 6BT, UK ${ }^{4}$ UCL Healthcare Biomagnetic and Nanomaterials Laboratory, 21 Albemarle Street, London W1S 4BS

\begin{abstract}
A series of highly dispersed $\mathrm{Ho}_{2} \mathrm{O}_{3}-\mathrm{Yb}_{2} \mathrm{O}_{3} / \mathrm{SiO}_{2}$ nanocomposites was synthesized using a liquidphase method and examined using Fourier transform infrared (FTIR) spectroscopy, X-ray diffraction (XRD), nitrogen adsorption-desorption, transmission electron microscopy (TEM), Scanning Electron Microscopy (SEM), and photon correlation spectroscopy (PCS). X-ray fluorescence spectrometry (XRF) confirmed a similar amount of weight percentage of $\mathrm{Ho}, \mathrm{Yb}$ and $\mathrm{Si}$ oxides in the prepared samples. Samples HoYbSi1 $\left(\mathrm{Ho}_{2} \mathrm{O}_{3}: \mathrm{Yb}_{2} \mathrm{O}_{3}: \mathrm{SiO}_{2}=0.5: 10: 89.5\right.$, wt. \%), HoYbSi2 $\left(\mathrm{Ho}_{2} \mathrm{O}_{3}: \mathrm{Yb}_{2} \mathrm{O}_{3}: \mathrm{SiO}_{2}=1: 10: 89\right.$, wt. \%) and $\mathrm{HoYbSi} 3\left(\mathrm{Ho}_{2} \mathrm{O}_{3}: \mathrm{Yb}_{2} \mathrm{O}_{3}: \mathrm{SiO}_{2}=2: 10: 88\right.$, wt. \%) calcined at $550{ }^{\circ} \mathrm{C}$ are amorphous. TEM and SEM analysis confirm a sphere-like morphology with a quite homogeneous size and shape. As compared with the initial silica, the agglomerated particles of nanocomposites in the aqueous medium are in the range from 200 to $850 \mathrm{~nm}$ according to PCS data. The effect of anionic polyacrylic acid (PAA) adsorption on fumed silica $\left(\mathrm{SiO}_{2}\right)$ and $\mathrm{Ho}_{2} \mathrm{O}_{3}-\mathrm{Yb}_{2} \mathrm{O}_{3} / \mathrm{SiO}_{2}$ nanocomposite surfaces on suspension stability was studied. The turbidymetry method was used to monitor the initial silica and triple nanooxides suspensions stability as a function of time.
\end{abstract}

Keywords: $\mathrm{Ho}_{2} \mathrm{O}_{3}-\mathrm{Yb}_{2} \mathrm{O}_{3} / \mathrm{SiO}_{2}$ nanocomposites, FTIR, Particle size distribution, Electrophoretic properties, Suspension stability

*Corresponding author: Iryna Sulym irynasulym@ukr.net 


\section{Introduction}

Nowadays, rare earth oxides (REOs) have attracted notable attention to many research communities due to their versatilities and potential applications in energy efficiency, heterogeneous catalysis, coating, antibacterial agent, computer devices, rechargeable batteries, laser, superconductors, as well as chemicals and biosensors (Magdalane et al. 2017; Magdalane et al. 2018; Adachi and Imanaka 1998; Dooley et al. 2011; Adachi and Imanaka 2001; Zheng et al. 2002; Joung et al. 2011). Among various REOs, the holmium $\left(\mathrm{Ho}_{2} \mathrm{O}_{3}\right)$ and ytterbium $\left(\mathrm{Yb}_{2} \mathrm{O}_{3}\right)$ oxides have become the center of attention for their unique chemical, electrical, optical, antibacterial, photocatalytic and electronics properties which made them suitable for the fabrication of dye-sensitized solar cell, antibacterial agent, photocatalysts, gas sensor, supercapacitors, optoelectronic devices and other applications (Zheng et al. 2014; Zinatloo-Ajabshir et al. 2017; Munawar et al. 2020; Guo et al. 2017; Park et al. 2016; Mekhemer 2004; Ghanashyam et al. 1999; Haumesser et al. 2002). Fumed silica $\left(\mathrm{SiO}_{2}\right)$ is one of the most widely used available inert supports with high specific surface area and thermal stability as well as excellent chemical resistance (Reddy et al. 2009; Sulym et al. 2016a; Sulym et al. 2016b). Moreover, $\mathrm{SiO}_{2}$ is one of the most popular adsorbents with the well-defined solid-liquid interface (Parida et al. 2006). In addition, the grain size and morphological features of nanostructured systems may remarkably affect their usages. In this way, size and shapecontrolled production of nanostructures, in particular, binary or ternary metal oxides, has become the center of attention of notable research efforts, lately (Zinatloo-Ajabshir et al. 2017; Vishwanathan et al. 2004; Bunjerd et al. 2007; Gao et al. 2008; Sulym et al. 2015; Goncharuk et al. 2019). So far, no experimental research has been done to understand the surface structure of the $\mathrm{Ho}_{2} \mathrm{O}_{3}-\mathrm{Yb}_{2} \mathrm{O}_{3} / \mathrm{SiO}_{2}$ nanocomposites as well as evaluate the electrophoretic parameters of their suspensions.

In this paper, we focused on studies of structural, morphological and electrokinetic features of highly dispersed $\mathrm{Ho}_{2} \mathrm{O}_{3}-\mathrm{Yb}_{2} \mathrm{O}_{3} / \mathrm{SiO}_{2}$ nanocomposites. Silica-supported $\mathrm{Ho}_{2} \mathrm{O}_{3}-\mathrm{Yb}_{2} \mathrm{O}_{3}$ ternary oxides were prepared using a liquid-phase method and investigated by means of FTIR, XRD, low temperature nitrogen adsorption-desorption technique, SEM, TEM and XRF techniques. The turbidimetric method was used for the stability and aggregation kinetic studies of the initial silica and mixed oxides suspensions without and with the polymer (poly(acrylic acid)-PAA with the anionic character). Additionally, the influence of changes in phase composition and surface structure on some electrophoretic parameters (particle size distribution, zeta potential) of $\mathrm{Ho}_{2} \mathrm{O}_{3}-\mathrm{Yb}_{2} \mathrm{O}_{3} / \mathrm{SiO}_{2}$ nanocomposites was determined using photon correlation spectroscopy.

\section{Experimental}

\section{Materials}


Initial fumed silica Aerosil ${ }^{\circledR} 300$ (Degussa, $\mathrm{S}_{\mathrm{BET}}=255 \mathrm{~m}^{2} / \mathrm{g}$ ), holmium(III) and ytterbium(III) nitrate pentahydrates (99.9\%, Aldrich) were used as base materials to prepare oxide composites.

Poly(acrylic acid) - PAA (Fluka, polydispersity index $\approx 1.2$ ) with an weight average molecular weight equal to $2000 \mathrm{Da}$ was used in the study.

\section{Preparation procedures}

$\mathrm{Ho}_{2} \mathrm{O}_{3}-\mathrm{Yb}_{2} \mathrm{O}_{3} / \mathrm{SiO}_{2}$ nanocomposites (Table 1) were prepared using a liquid-phase method and subjected to thermal treatments at $550{ }^{\circ} \mathrm{C}$ (Fig. 1).

Table 1 Some characteristics of initial silica and $\mathrm{Ho}_{2} \mathrm{O}_{3}-\mathrm{Yb}_{2} \mathrm{O}_{3} / \mathrm{SiO}_{2}$ nanocomposites

\begin{tabular}{ccccc}
\hline & \multirow{2}{*}{$\begin{array}{c}\text { Samples composition } \\
\text { Samples ID }\end{array}$} & \multicolumn{3}{c}{ CXride wt. \%) } \\
\cline { 3 - 5 } & $\mathrm{SiO}_{2}$ & $\mathrm{Ho}_{2} \mathrm{O}_{3}$ & $\mathrm{Yb}_{2} \mathrm{O}_{3}$ & $\mathrm{SiO}_{2}$ \\
\hline $\mathrm{SiO}_{2}$ & - & - & 100 \\
$\mathrm{HoYbSi} 1$ & $\mathrm{Ho}_{2} \mathrm{O}_{3}(0.5) \mathrm{Yb}_{2} \mathrm{O}_{3}(10) \mathrm{SiO}_{2}$ & $0.556 \pm 0.025$ & $12.4 \pm 0.3$ & 87 \\
$\mathrm{HoYbSi} 2$ & $\mathrm{Ho}_{2} \mathrm{O}_{3}(1) \mathrm{Yb}_{2} \mathrm{O}_{3}(10) \mathrm{SiO}_{2}$ & $1.099 \pm 0.043$ & $12.8 \pm 0.3$ & 86 \\
$\mathrm{HoYbSi} 3$ & $\mathrm{Ho}_{2} \mathrm{O}_{3}(2) \mathrm{Yb}_{2} \mathrm{O}_{3}(10) \mathrm{SiO}_{2}$ & $2.19 \pm 0.006$ & $12.4 \pm 0.3$ & 85 \\
\hline
\end{tabular}

For the synthesis aqueous salt solutions of $\mathrm{Ho}\left(\mathrm{NO}_{3}\right)_{3}(0.2 / 0.4 / 0.8 \mathrm{~g})$ and $\mathrm{Yb}\left(\mathrm{NO}_{3}\right)_{3}(4.68 \mathrm{~g})$ were added to $15 \mathrm{~g}$ of fumed silica powder (previously calcined at $500^{\circ} \mathrm{C}$ ) at room temperature. The mixtures were stirred $(300 \mathrm{rpm})$ in the beaker using a propeller stirrer for a half-hour (Fig. 1). Water was removed from the mixtures in a rotary evaporator. The solid was then dried and calcined at $550{ }^{\circ} \mathrm{C}$ for 1 hour in a muffle furnace. The content of grafted $\mathrm{Ho}_{2} \mathrm{O}_{3}$ was varied from 0.5 to 2 wt. \% whereas $\mathrm{Yb}_{2} \mathrm{O}_{3}$ content was held constant at 10 wt. \%. The samples were marked as HoYbSi1, HoYbSi2 and HoYbSi3, respectively (Table 1). Initial silica Aerosil ${ }^{\circledR} 300$ was used as a control sample.

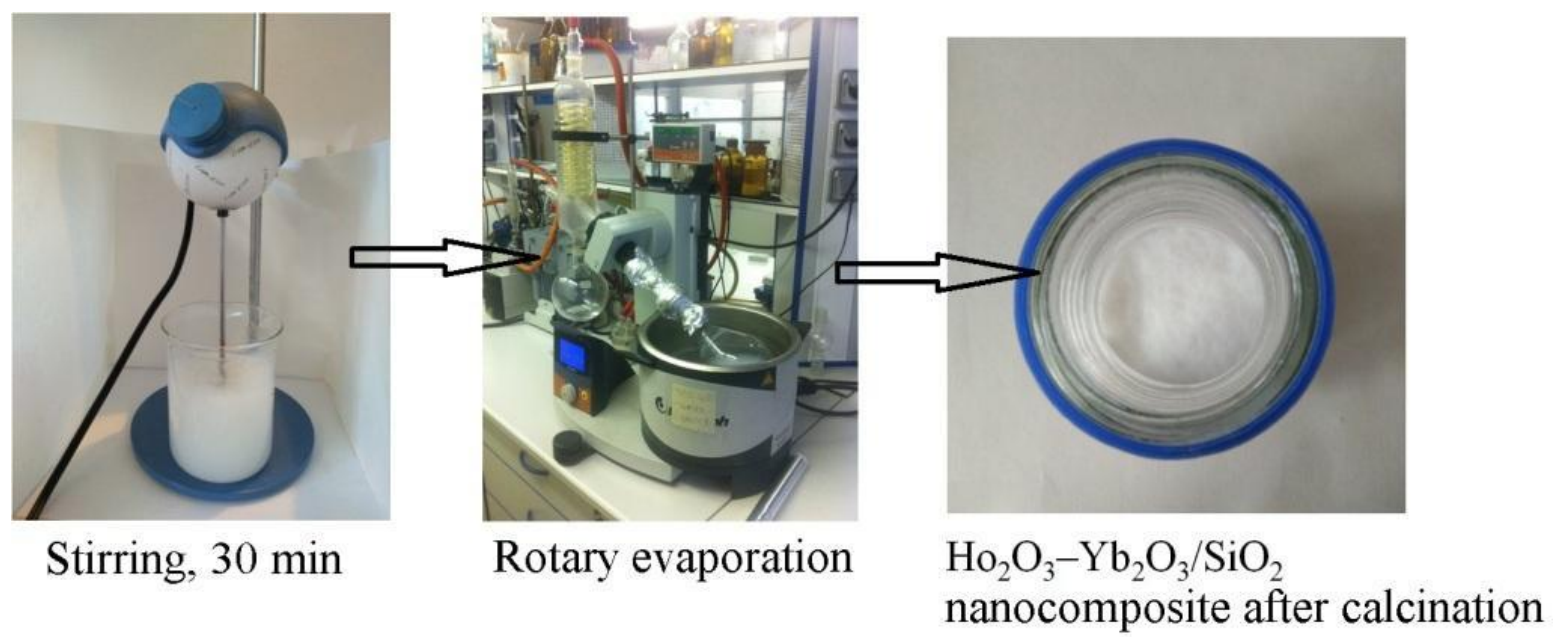

Fig. 1 The preparation of silica-supported holmium-ytterbium nanocomposites 


\section{Methods}

X-ray diffraction (XRD) patterns were recorded at room temperature using a DRON-3M diffractometer (Burevestnik, St.-Petersburg, Russia) with $\mathrm{Cu} \mathrm{K}_{\alpha}(\lambda=0.15418 \mathrm{~nm})$ radiation and a Ni filter in the $2 \theta$ range from $10^{\circ}$ to $70^{\circ}$.

To analyze the textural characteristics of initial $\mathrm{SiO}_{2}$ and $\mathrm{Ho}_{2} \mathrm{O}_{3}-\mathrm{Yb}_{2} \mathrm{O}_{3} / \mathrm{SiO}_{2}$ nanocomposites, lowtemperature $(77.4 \mathrm{~K})$ nitrogen adsorption-desorption isotherms were recorded using an automatic gas adsorption analyzer ASAP 2405N (Micromeritics Instrument Corp., USA) after outgassing the samples at $110^{\circ} \mathrm{C}$ for 2 hours in a vacuum chamber. The values of the specific surface area $\left(S_{B E T}\right)$ were calculated according to the standard BET method (Gregg and Sing 1982). The total pore volume $V_{p}$ was evaluated by converting the volume of adsorbed nitrogen at $p / p_{0}=0.98-0.99$ ( $p$ and $p_{0}$ denote the equilibrium pressure and saturation pressures of nitrogen at $77.4 \mathrm{~K}$, respectively) to the volume of liquid nitrogen per gram of adsorbent. The nitrogen desorption data were used to compute the pore size distributions (PSDs, differential $f_{\mathrm{V}} \sim \mathrm{d} V_{\mathrm{p}} / \mathrm{d} R$ and $f_{\mathrm{S}} \sim \mathrm{d} S / \mathrm{d} R$ ) using a self-consistent regularization (SCR) procedure under nonnegativity condition $\left(f_{\mathrm{V}} \geq 0\right.$ at any pore radius $\left.R\right)$ at a fixed regularization parameter $\alpha=0.01$ with a complex pore model with voids (V) between spherical nonporous nanoparticles packed in random aggregates (V/SCR model) (Gun'ko et al. 2009; Gun'ko 2014). The differential PSDs with respect to pore volume $f_{\mathrm{V}} \sim \mathrm{d} V / \mathrm{d} R, \int f_{\mathrm{V}} \mathrm{d} R \sim V_{\mathrm{p}}$ were re-calculated to incremental PSD (IPSD) at $\Phi_{\mathrm{V}}\left(R_{i}\right)=\left(f_{\mathrm{V}}\left(R_{i+1}\right)\right.$ $\left.+f_{\mathrm{V}}\left(R_{i}\right)\right)\left(R_{i+1}-R_{i}\right) / 2$ at $\left.\sum \Phi_{\mathrm{V}}\left(R_{i}\right)=V_{\mathrm{p}}\right)$. The $f_{\mathrm{V}}$ and $f_{\mathrm{S}}$ functions were also used to calculate contributions of micropores ( $V_{\text {micro }}$ and $S_{\text {micro }}$ at $\left.0.35 \mathrm{~nm}<R<1 \mathrm{~nm}\right)$, mesopores $\left(V_{\text {meso }}\right.$ and $S_{\text {meso }}$ at $1 \mathrm{~nm}<R<25 \mathrm{~nm}$ ), and macropores ( $V_{\text {macro }}$ and $S_{\text {macro }}$ at $25 \mathrm{~nm}<R<100 \mathrm{~nm}$ ).

The chemical composition of the nanocomposites was determined by X-ray fluorescence spectrometry (XRF) (Axios mAX, PANalytical, Netherlands).

Fourier transform infrared (FTIR) spectra of powdered samples (grinded with dry $\mathrm{KBr}$ at the mass ratio 1 : 9) over the $4000-400 \mathrm{~cm}^{-1}$ range were recorded using a Thermo Nicolet FTIR spectrometer with a diffuse reflectance mode. The integral intensity of the peaks at 3748 and $1861 \mathrm{~cm}^{-1}\left(I_{3748}\right.$ and $I_{1861}$, respectively) was calculated from the FTIR spectra to estimate the accessible surface area of silica in all samples.

The particulate morphology was analyzed using field emission Scanning Electron Microscopy (SEM) employing a QuantaTM 3D FEG (FEI Company, USA) apparatus operating at a voltage of $30 \mathrm{kV}$. Powdered samples were placed on circular aluminum stubs with double sticky carbon tape and then covered with Pd/Au (EM SCD005, Leica).

Transmission electron microscope (TEM) images were captured using a JEOL 1200 EX microscope with a $120 \mathrm{kV}$ acceleration voltage using Gatan Digital Micrograph software. Samples were prepared by pipetting $5 \mu 1$ of the sample onto carbon-coated copper TEM grids, which were allowed to dry at room 
temperature. Size analysis was performed using image analysis software ImageJ. For each sample $>200$ particles were measured to get an average diameter and standard deviation.

Analysis of the particle-size distribution (PSD) for the aqueous suspensions of different fine oxides were carried out using a Zetasizer 3000 (Malvern Instruments) apparatus based on photon correlation spectroscopy (PCS, $\lambda=633 \mathrm{~nm}, \Theta=90^{\circ}$, software version 1.3). The aqueous suspensions of oxides 0.1 wt. \% were prepared using an ultrasonic disperser for $5 \mathrm{~min}$ (Sonicator Misonix Inc., power $500 \mathrm{~W}$ and frequency $22 \mathrm{kHz}$ ) prior to the measurements. One result was the average of three measurements. The measurement error did not exceed $5 \%$.

The electrokinetic (zeta potential determination), mean aggregates (flocks) size and stability measurements were performed in the supporting electrolyte solution $-\mathrm{NaCl}$ with concentration 0.001 mole/L and in the poly(acrylic acid) presence with concentration $100 \mathrm{mg} / \mathrm{L}$. The examined systems were as follows: $\mathrm{SiO}_{2}-\mathrm{NaCl}$; $\mathrm{SiO}_{2}-\mathrm{NaCl}-\mathrm{PAA} ; \mathrm{HoYbSi1-NaCl}$; HoYbSi1-NaCl-PAA; HoYbSi2-NaCl; HoYbSi2-NaCl-PAA; HoYbSi3-NaCl andHoYbSi3-NaCl-PAA. All measurements were carried out at 25 ${ }^{\circ} \mathrm{C}$ in the natural suspension $\mathrm{pH}$ changing in the range of 3.85-5.42. This polymer has a weak anionic character due to the presence of carboxyl groups in their macromolecules. The $\mathrm{pK}_{\mathrm{a}}$ value of PAA was about 4.5 (Chibowski et al. 2003) - at $\mathrm{pH} 4.5$ the degree of polymer dissociation is 0.5 . At $\mathrm{pH} 3$ and 5 the degree of PAA dissociation was equal to 0.03 and 0.76 , respectively. Solid suspensions (without and with PAA) for the electrophoretic mobility measurements were prepared to add $0.003 \mathrm{~g}$ of the silica or appropriate composite to $20 \mathrm{~mL}$ of $\mathrm{NaCl}$ or $\mathrm{NaCl}+\mathrm{PAA}$ solutions. The suspension was sonicated for 3 min (ultrasonicator XL 2020, Misonix). After this time the suspension was divided into two parts. The first one was subjected to mean aggregates (flocks) size determination and the second one - to electrophoretic mobility determination. Both parameters were measured using the Zetasizer Nano ZS with the universal dip cell. The zeta potential was calculated with the special computer program using the Henry equation (Hunter 1981):

$$
U_{e}=\frac{2 \varepsilon_{0} \varepsilon \zeta}{3 \eta} f(\kappa a)
$$

where: $U_{e}$ - electrophoretic mobility, $\varepsilon$ - dielectric constant, $\varepsilon_{0}$ - electric permeability of vacuum, $\zeta$ - zeta potential, $\eta$ - viscosity, $f(\kappa a)-$ Henry function.

The stability measurements of the solid suspensions in the absence and presence of PAA were performed using the apparatus Turbiscan Lab ${ }^{\text {Expert }}$ with cooling module TLAb cooler. The suspension was prepared to add $0.2 \mathrm{~g}$ of the solid to $20 \mathrm{~mL}$ of $\mathrm{NaCl}$ or $\mathrm{NaCl}+\mathrm{PAA}$ solutions. Changes in the suspension stability were monitored for $15 \mathrm{hrs}$ (single scans were collected every $15 \mathrm{~min}$ ). The results were presented in the form of intensities of light transmission (at the angle of $0^{\circ}$ in relation to the direction of starting light beam with wavelength $880 \mathrm{~nm}$ ) and backscattering (the light scattered at the angle of $135^{\circ}$ in relation to the direction of starting light beam) as a function of time. The transmission and backscattering data enable calculation of the stability coefficient TSI (Turbiscan Stability Index), the aggregates size 
(flocks) and the velocity of their migration (Snabre and Mills 1994). The values of aggregates sizes obtained by the use of Zetasizer and Turbiscan were compared. The stability parameters were calculated

using the programs TLab EXPERT 1.13 and Turbiscan Easy Soft from the dependencies:

$T S I=\sqrt{\frac{\sum_{i=1}^{n}\left(x_{i}-x_{B S}\right)^{2}}{n-1}}$

where: $x_{i}-$ average backscattering for each minute of measurement, $x_{B S}-$ average $x_{i}, n-$ number of scans (repetitions of single measurement during the total time of the experiment),

and:

$V(\phi, d)=\frac{\left|\rho_{p}-\rho_{c}\right| g d^{2}}{18 v} \cdot \frac{[1-\phi]}{\left[1+\frac{4.6 \phi}{(1-\phi)^{3}}\right]}$

where: $\mathrm{v}-$ particles migration velocity, $\rho_{\mathrm{c}}$ - continuous phase density, $\rho_{\mathrm{p}}$ - particle density, $\mathrm{d}-$ particle mean diameter, $v$ - continuous phase dynamic viscosity, $\phi$ - volume fraction of dispersed solid.

The TSI coefficient value varies in the range from 0 to 100 , and the value close to 100 is obtained for extremely unstable systems.

\section{Results and discussion}

The XRD patterns showed that all samples remained amorphous after their heating at $550{ }^{\circ} \mathrm{C}$ (Fig. 2). A broad halo centered at about $22^{\circ}$ refers to the non-crystalline phase of silica. A shoulder at $32^{\circ}$ on the XRPD patterns of the HoYbSi samples can generate diffuse scattering from the amorphous components such as $\mathrm{Ho}_{2} \mathrm{O}_{3}$ and $\mathrm{Yb}_{2} \mathrm{O}_{3}$.

Semi-quantitative chemical analysis performed using XRF revealed similar compositions of mixed oxides in respect to $\mathrm{Ho}, \mathrm{Yb}$ and $\mathrm{Si}$ (Table 1).

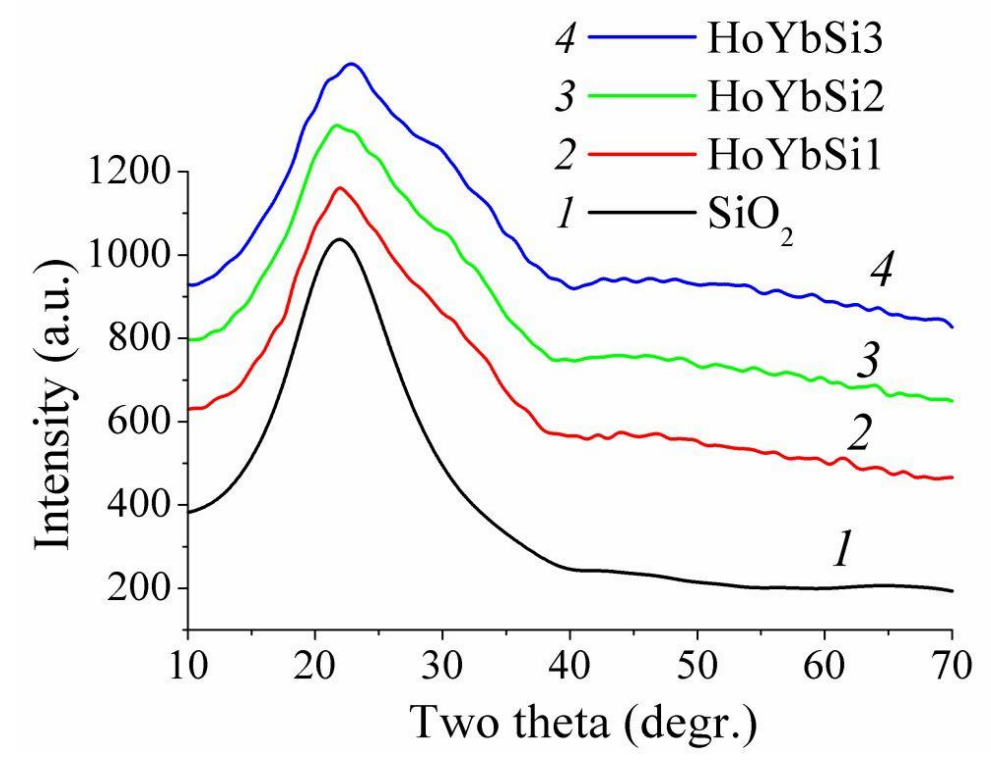

Fig. 2 XRD patterns of initial $\mathrm{SiO}_{2}(1)$ and the triple nanooxides (2-4) calcined at $550{ }^{\circ} \mathrm{C}$ 
The nitrogen adsorption-desorption isotherms obtained for initial silica and composites (Figure 3a) demonstrate sigmoidal-shaped behavior with a narrow hysteresis loop of the $\mathrm{H} 3$ type in the $p / p_{0}$ range

between 0.8 and 1.0. This indicates the formation of aggregates with initially non-porous particles, which are characterized by textural porosity. The shape of the isotherms for all the nanocomposites corresponds to type II according to IUPAC classification (Gregg and Sing 1982; Gun'ko 2014). The incremental pore (voids between particles in aggregates) size distribution functions (Figure 3b) show that the textural characteristics change after the modification (See Table 2).

Table 2 Textural characteristics of initial and silica-supported holmium-ytterbium nanocomposites ${ }^{a}$

\begin{tabular}{cccccccccc}
\hline Sample & $\begin{array}{c}\mathrm{S}_{\text {BET, }}, \\
\mathrm{m}^{2} / \mathrm{g}\end{array}$ & $\begin{array}{c}\mathrm{S}_{\text {micro, }} \\
\mathrm{m}^{2} / \mathrm{g}\end{array}$ & $\begin{array}{c}\mathrm{S}_{\text {meso, }} \\
\mathrm{m}^{2} / \mathrm{g}\end{array}$ & $\begin{array}{c}\mathrm{S}_{\text {macro, }}, \\
\mathrm{m}^{2} / \mathrm{g}\end{array}$ & $\begin{array}{c}V_{\text {micro, }} \\
\mathrm{cm}^{3} / \mathrm{g}\end{array}$ & $\begin{array}{c}V_{\text {meso }}, \\
\mathrm{cm}^{3} / \mathrm{g}\end{array}$ & $\begin{array}{c}V_{\text {macro, }}, \\
\mathrm{cm}^{3} / \mathrm{g}\end{array}$ & $\begin{array}{c}V_{\mathrm{p},} \\
\mathrm{cm}^{3} / \mathrm{g}\end{array}$ & $\begin{array}{c}\mathrm{R}_{\mathrm{p}, \mathrm{V}} \\
\mathrm{nm}\end{array}$ \\
\hline $\mathrm{SiO}_{2}$ & 256 & 4 & 252 & 0.0 & 0.002 & 0.581 & 0.012 & 0.595 & 6 \\
$\mathrm{HoYbSi1}$ & 212 & 9 & 111 & 92 & 0.004 & 0.550 & 0.696 & 1.25 & 35 \\
$\mathrm{HoYbSi2}$ & 208 & 9 & 153 & 46 & 0.004 & 0.501 & 0.745 & 1.25 & 25 \\
$\mathrm{HoYbSi3}$ & 200 & 10 & 133 & 57 & 0.004 & 0.453 & 0.813 & 1.27 & 27
\end{tabular}

${ }^{a}$ Note. Specific surface area in total $\left(S_{B E T}\right)$, of nanopores $\left(S_{\text {micro }}\right)$, mesopores $\left(S_{\text {meso }}\right)$, macropores $\left(S_{\text {macro }}\right)$ and respective specific pore volumes $\left(V_{p}, V_{\text {micro }}, V_{\text {meso }}, V_{\text {macro }}\right) . R_{p, V}$ represents the average pore radius determined from the differential pore size distributions with respect to the pore volume

The specific surface area (Table 2, $S_{\mathrm{BET}}$ ) does not demonstrate a significant reduction after grafting of $\mathrm{Ho}_{2} \mathrm{O}_{3}-\mathrm{Yb}_{2} \mathrm{O}_{3}$. However, the total pore volume $\left(V_{\mathrm{p}}\right)$ increases for the triple nanooxides is doubled compared to the initial silica. It is seen that the pore average radii in $\mathrm{HoYbSi}$ samples are five times greater than that of unmodified $\mathrm{SiO}_{2}$. This was confirmed by changes in the IPSD (Fig. 3b). Furthermore, the analysis of the results suggests existence of predominantly mesoporosity of aggregates for initial $\mathrm{SiO}_{2}$ and meso/macroporosity for composites (Fig. 3b; Table 2).
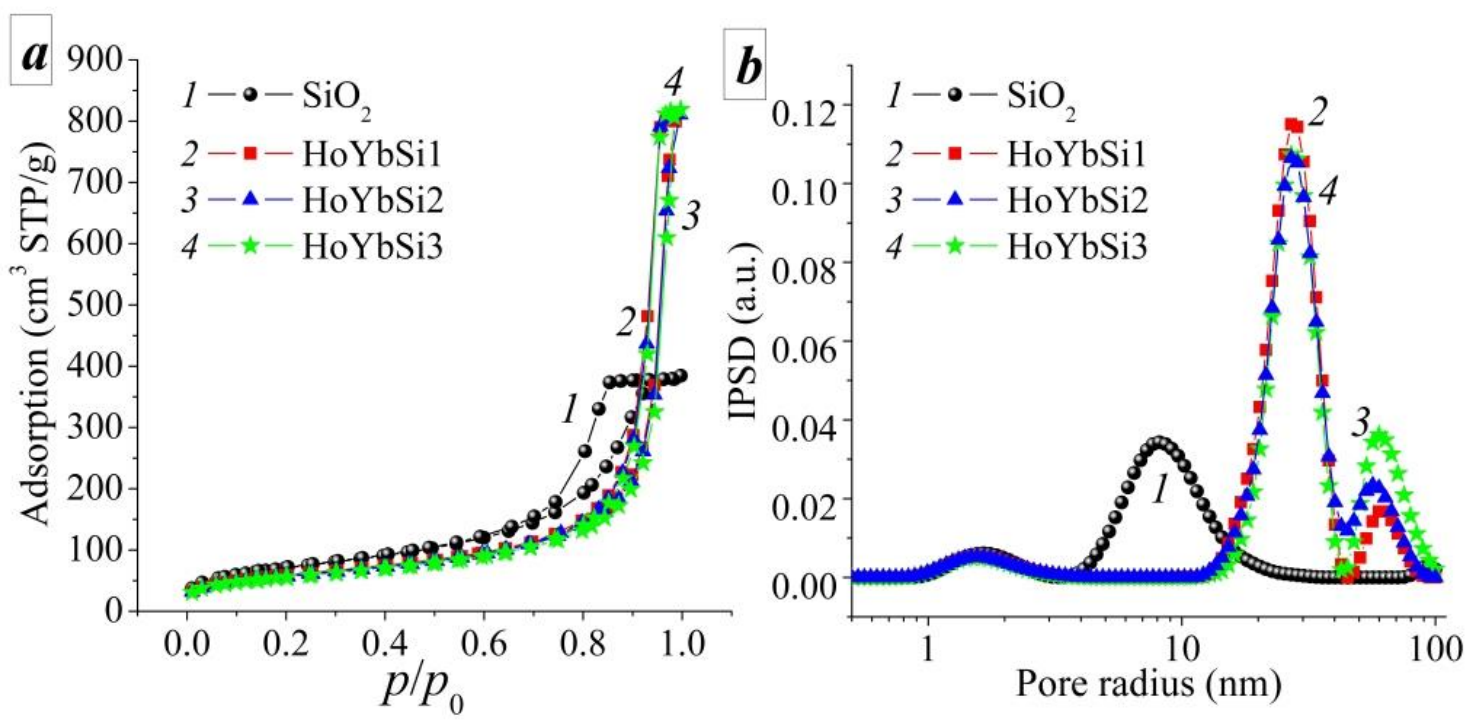

Fig. 3 Nitrogen adsorption-desorption isotherms $(a)$ and incremental pore size distributions $(b)$ for initial silica (curve 1), the triple nanooxides (curves $2-4$ ) calcined at $550{ }^{\circ} \mathrm{C}$ 
Figure 4 shows FTIR spectra of initial and silica-supported holmium-ytterbium nanocomposites in the wavenumber range from 4000 to $1500 \mathrm{~cm}^{-1}$. The broad bands of high intensity at $3000-3750 \mathrm{~cm}^{-1}$

centred at around $3400 \mathrm{~cm}^{-1}$ attributed to the stretching mode of the $\mathrm{O}-\mathrm{H}$ bonds of surface absorbed water and hydroxyl groups (Kapridaki et al. 2013). The peak located at $1634 \mathrm{~cm}^{-1}$ represents the bending vibrations of absorbed water (Ren et al. 2013). A reliable method for estimating the ratio of the free surface with free $\mathrm{OH}$ groups to silica volume is the normalizing of the integrated intensity of the 3748 $\mathrm{cm}^{-1}$ band $\left(I_{3748}\right.$, i.e., a fraction of a free surface with free $\mathrm{OH}$ groups) to the integrated intensity of a band at $1861 \mathrm{~cm}^{-1}\left(I_{1861}\right)$ corresponding to the $\mathrm{Si}-\mathrm{O}$ stretching vibrations and correlates to the total amount of silica in a sample (Maggi et al. 1998). It can be seen that the normalized integrated intensity $\left(I_{3748} / I_{1861}\right)$ decreases for all triple oxides (Fig. 4, curves 2 - 4) in comparison to the initial silica. We may assume that $\mathrm{Ho}_{2} \mathrm{O}_{3}-\mathrm{Yb}_{2} \mathrm{O}_{3}$ oxides do not cover the whole surface of fumed silica.

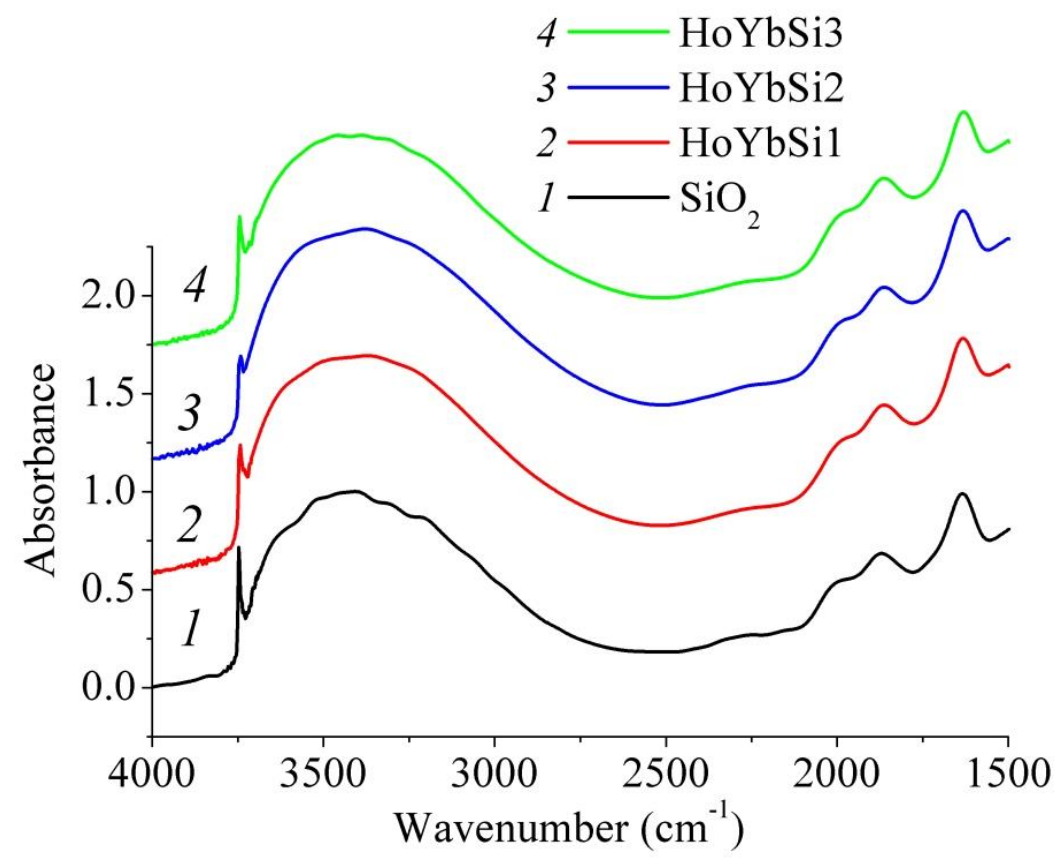

Fig. 4 FTIR spectra of initial $\mathrm{SiO}_{2}(1)$ and the triple nanooxides (2-4) calcined at $550{ }^{\circ} \mathrm{C}$

Figure 5 shows $\mathrm{SEM}$ micrographs of the initial $\mathrm{SiO}_{2}$ and synthesized nanocomposites. As can be seen from the photographs, the primarily amorphous structure is observed after calcination at $550{ }^{\circ} \mathrm{C}$ for all samples, moreover, nanocomposites (Fig. 5b,c,d) look like less aggregated than initial silica (Fig. 5a). SEM images and particle size distributions (PSD) show that samples are uniform with size in the range of $8-28 \mathrm{~nm}$ for initial $\mathrm{SiO}_{2}$ (Fig. 5e) and $14-26 \mathrm{~nm}$ for nanocomposites (Fig. 5f,g,h), as well as spherical tendency is observed.

TEM images of silica-supported holmium-ytterbium nanocomposites (Figures 6b,c,d) show the formation of $\mathrm{Ho}_{2} \mathrm{O}_{3}-\mathrm{Yb}_{2} \mathrm{O}_{3}$ particles (dark structures) at the silica surface (light structures). The aggregated structures of grafted oxides varying between 4 and $12 \mathrm{~nm}$ in size are well observed for 
HoYbSi1-3 (Figs. 6f,g,h). The average particle sizes for the triple nanooxides are $6-9 \mathrm{~nm}$ (Figs. 6f,g,h), while the primary particle size is $6 \mathrm{~nm}$ (Fig. 6e). Nanocomposites look more compacted than initial silica.
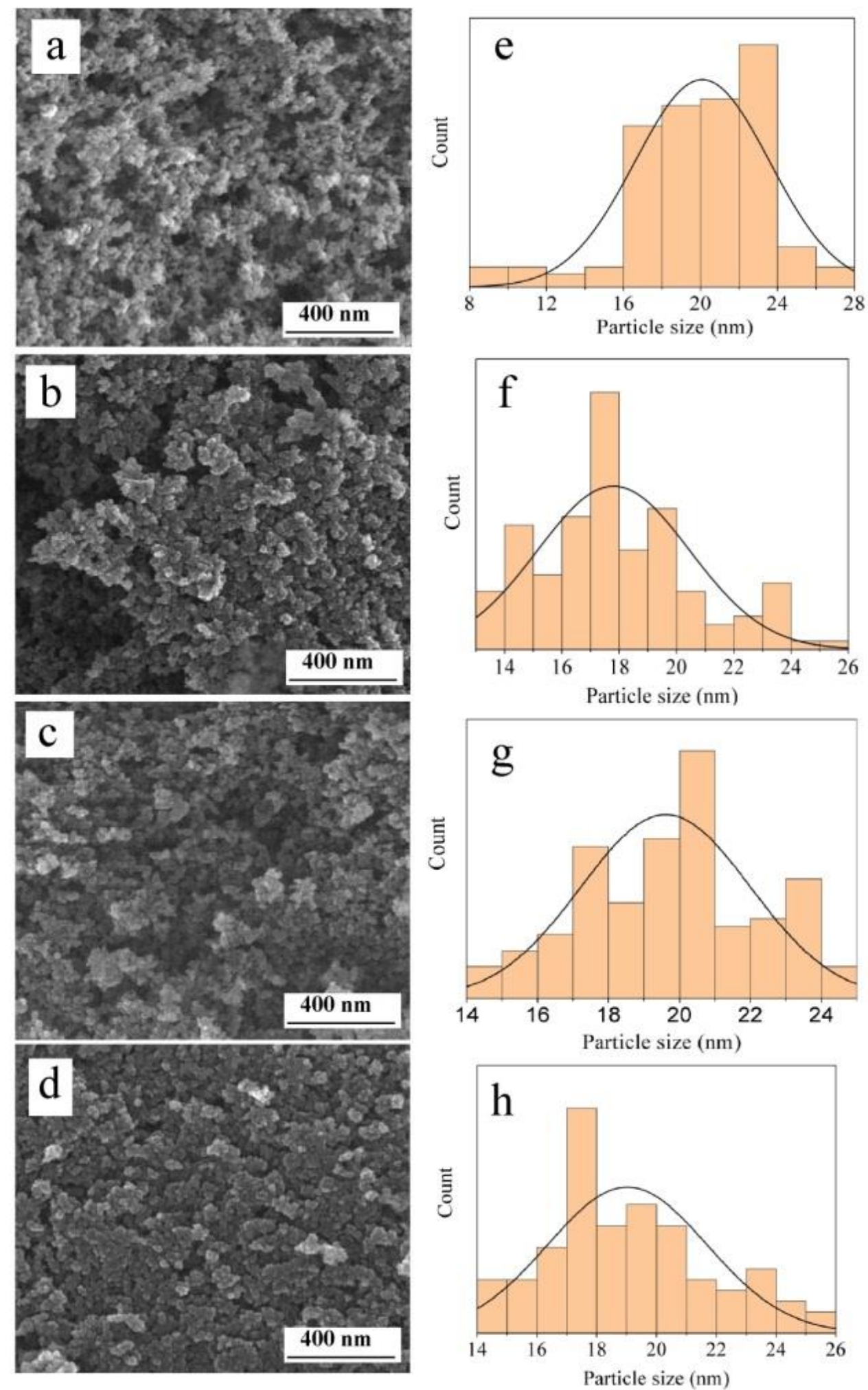

Fig. 5 SEM images (left) and PSD (right) for initial $\mathrm{SiO}_{2}$ (a, e), HoYbsi1(b, f), HoYbSi2 (c, g) and HoYbSi3 (d, h) samples calcined at $550{ }^{\circ} \mathrm{C}$

It is known that the particle size will always be smaller once measured in TEM compared to SEM (resolution matter). SEM has used for imaging the surface of the nanoparticle on a submicroscopic scale. 
In contrast, the use of TEM is to image the internal structure of the nanoparticle on a nanometer scale.

That why particles appear $\sim 3 \%$ larger in the SEM than in the TEM microscope (Jacquelyn and Laura 1 2014).
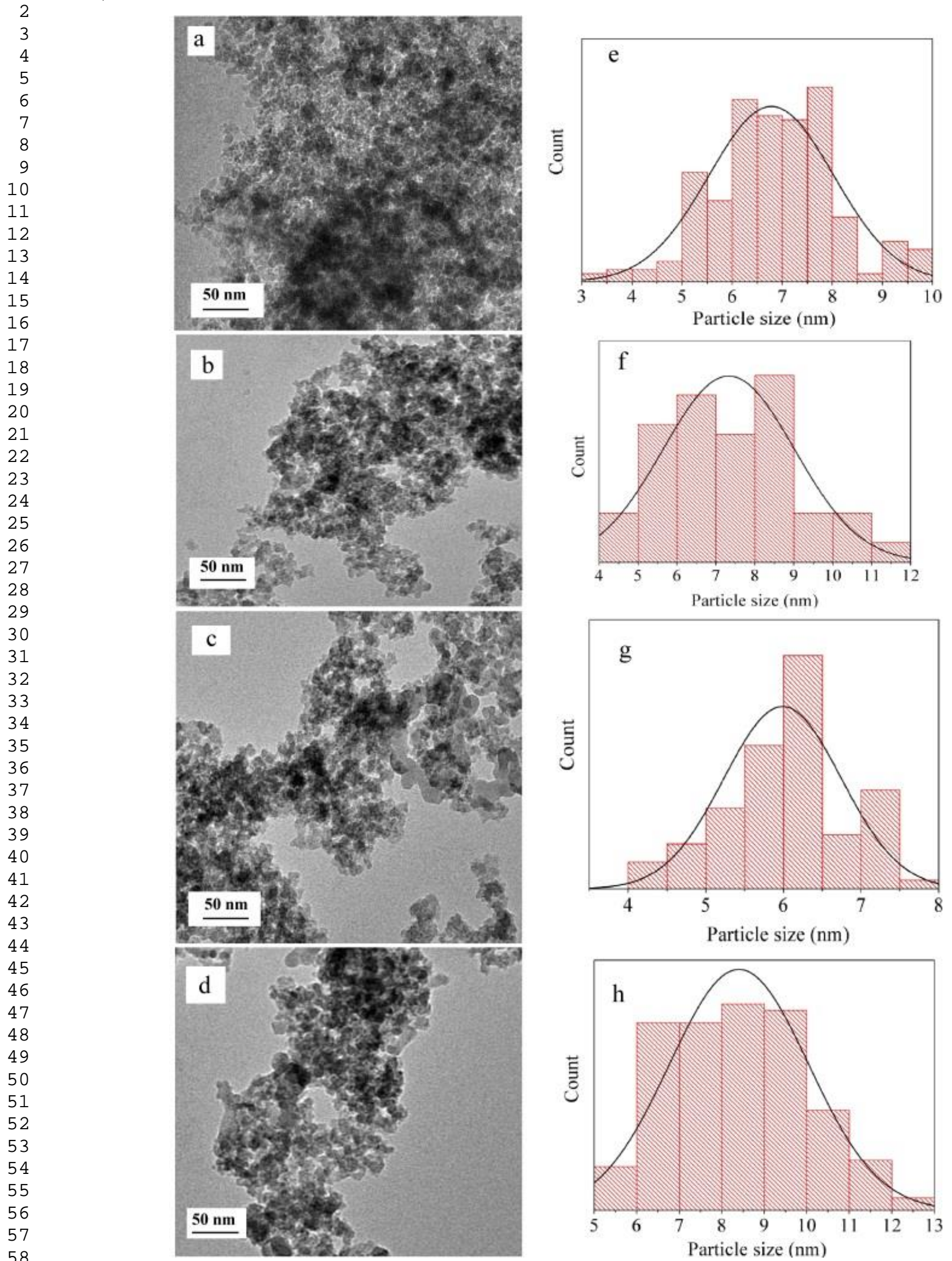

Fig. 6 TEM images (left) and PSD (right) for initial $\mathrm{SiO}_{2}(\mathrm{a}, \mathrm{e}), \mathrm{HoYbSi1}(\mathrm{b}, \mathrm{f}), \mathrm{HoYbSi} 2$ (c, g) and $\mathrm{HoYbSi3}(\mathrm{d}, \mathrm{h})$ samples calcined at $550{ }^{\circ} \mathrm{C}$ 
Dispersion of the initial silica and triple nanooxides in aqueous was controlled by photon correlation spectroscopy (PCS). As can be seen from the PSD, nanocomposites exhibit polymodal

distribution and a tendency to form larger agglomerates of particles (Figs. 7bcd) in comparison to initial $\mathrm{SiO}_{2}$ (Fig. 7a). The increase of PSD in aqueous suspensions can be associated with a change in particle size during the formation of a new phase of $\mathrm{Ho}_{2} \mathrm{O}_{3}-\mathrm{Yb}_{2} \mathrm{O}_{3}$ during the synthesis, as well as with the influence of changes in the surface structure of the oxide composites on the aggregation processes in an aqueous medium.
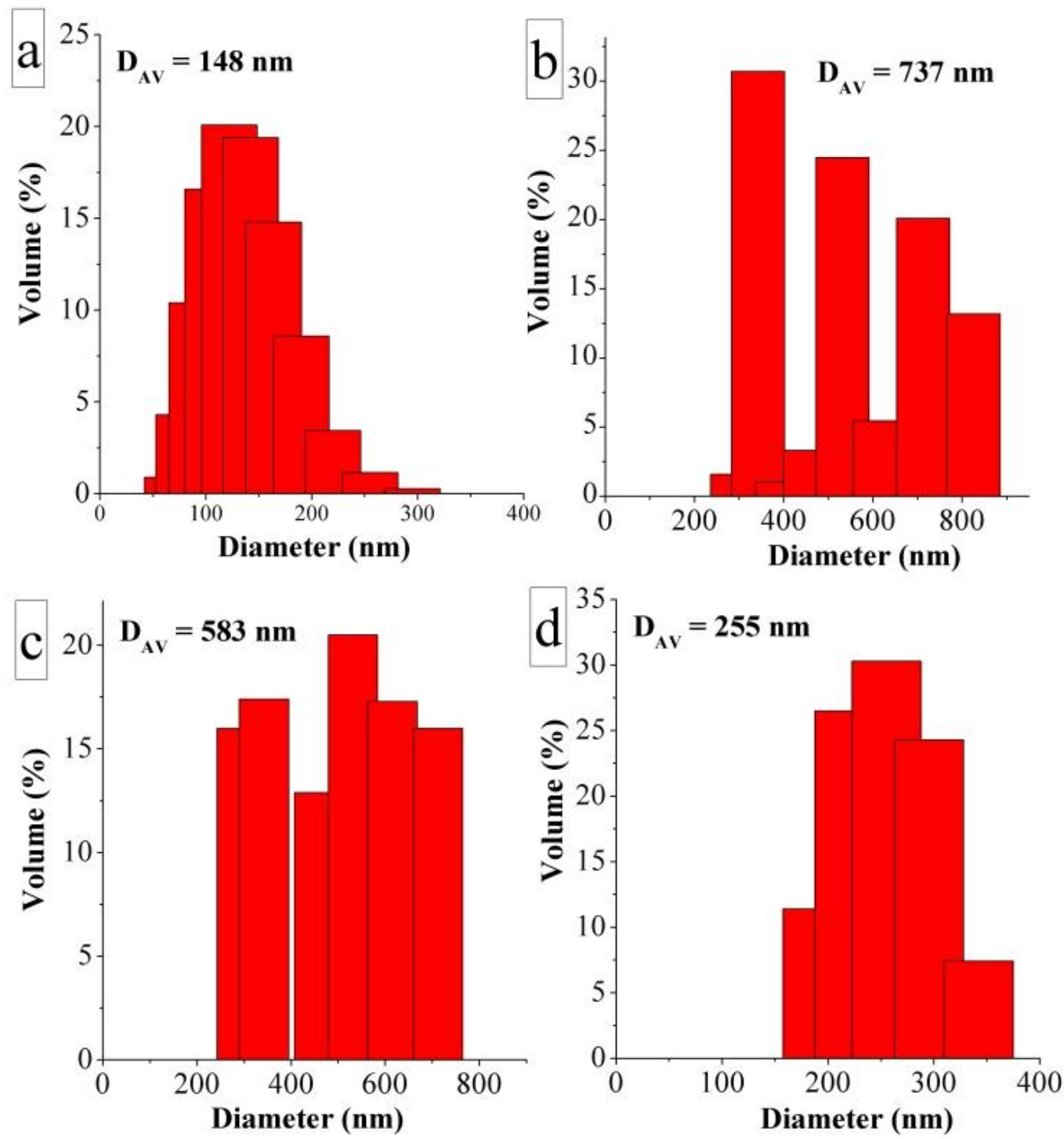

Fig. 7 The PSD for initial $\mathrm{SiO}_{2}$ (a), HoYbSi1(b), HoYbSi2 (c) and HoYbSi3 (d) samples calcined at $550{ }^{\circ} \mathrm{C}$

Table 3 presents the values of stability coefficients obtained for examined suspensions without and with PAA. The TSIs were calculated for each system after $5 \mathrm{~min}, 1 \mathrm{~h}$ and $24 \mathrm{hrs}$ from the beginning of the experiment. Additionally, Figure 8 presents the destabilization kinetics for all examined suspensions expressed as: (a) transmission - T and (b) TSI changes, during the 24 hours of stability measurement. 
Table 3 TSI stability coefficients obtained after $15 \mathrm{~min}, 1 \mathrm{~h}$ and $24 \mathrm{hrs}$ from the beginning of the experiment for the examined suspensions without and with PAA

\begin{tabular}{cccc}
\hline Sample & $\begin{array}{c}\text { TSI } \\
(\text { after 15 min })\end{array}$ & $\begin{array}{c}\text { TSI } \\
\text { (after 1 h) }\end{array}$ & $\begin{array}{c}\text { TSI } \\
\text { (after 24 hrs) }\end{array}$ \\
\hline $\mathrm{SiO}_{2}-\mathrm{NaCl}$ & 2.0 & 5.2 & 13.8 \\
$\mathrm{SiO}_{2}-\mathrm{NaCl}-\mathrm{PAA}$ & 2.6 & 5.8 & 14.8 \\
$\mathrm{HoYbSi1}-\mathrm{NaCl}$ & 28.3 & 46.5 & 63.6 \\
$\mathrm{HoYbSi1}-\mathrm{NaCl}-\mathrm{PAA}$ & 22.2 & 47.2 & 63.0 \\
$\mathrm{HoYbSi2}-\mathrm{NaCl}$ & 9.6 & 32.4 & 55.3 \\
$\mathrm{HoYbSi2}-\mathrm{NaCl}-\mathrm{PAA}$ & 27.5 & 42.8 & 59.7 \\
$\mathrm{HoYbSi3}-\mathrm{NaCl}$ & 21.0 & 45.9 & 64.1 \\
$\mathrm{HoYbSi3}-\mathrm{NaCl}-\mathrm{PAA}$ & 17.4 & 43.1 & 63.5 \\
\hline
\end{tabular}

Analysis of the data in Table 3 indicates that initial silica suspension was characterized by the highest stability - TSI assumes the lowest value among all systems. In the case of nanocomposites (HoYbSi1, HoYbSi2 and HoYbSi3) their stability decreases considerably and TSI values change in the range 55.364.1. The addition of anionic polymer minimally influences the stability conditions of the examined systems. Moreover, for all studied suspensions their stability decreased during the turbidimetric experiments (TSI values decrease as a function of time).
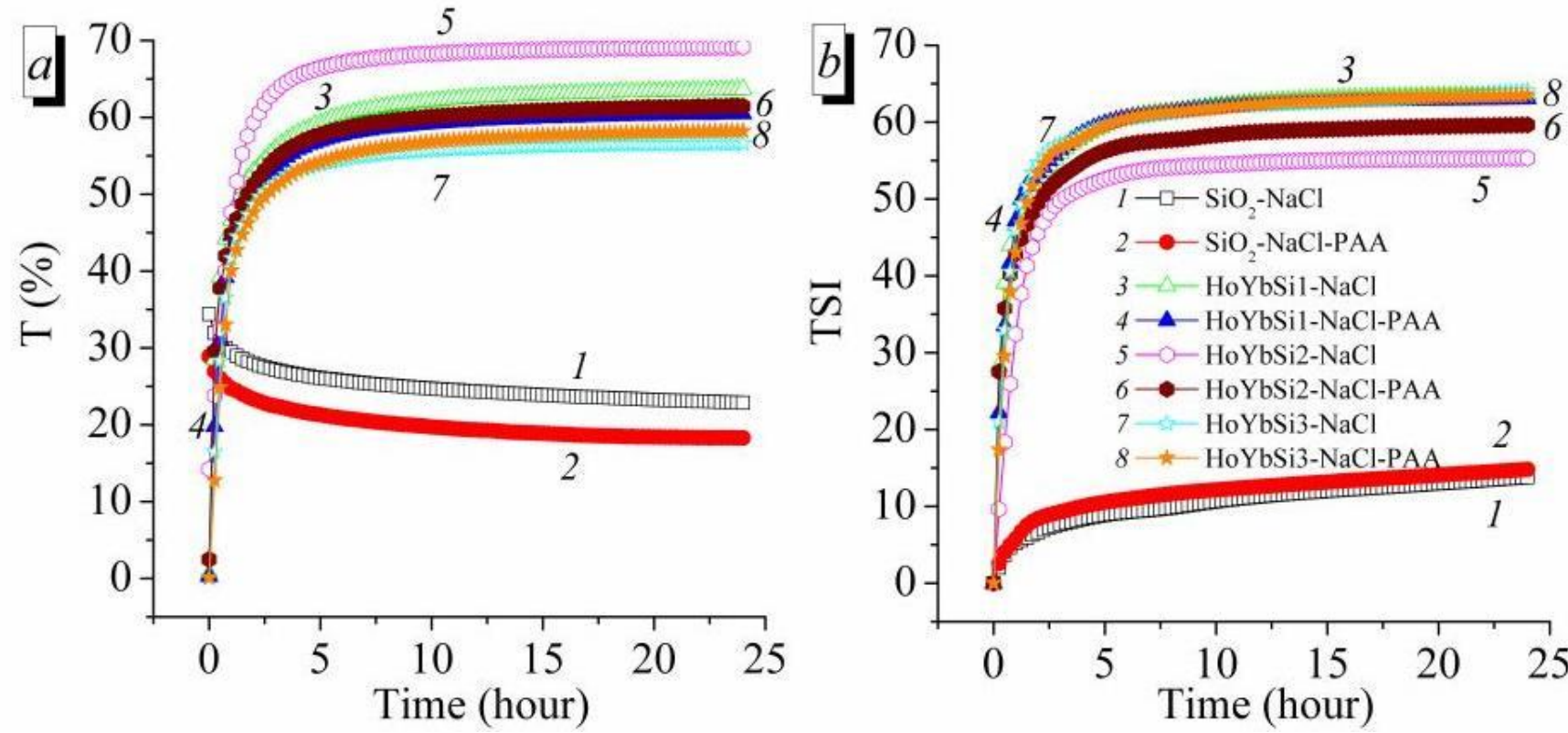

Fig. 8 The destabilization kinetics for all examined suspensions expressed as: (a) transmission $\mathrm{T}$ and (b) TSI changes, during the 24 hours of stability measurement

Changes in the electrokinetic potential zeta of the solid particles (initial silica and its composites) dispersed in supporting electrolyte solution without and with the polymer, as well as mean aggregate diameters (obtained from measurements performed by the use of Zetasizer) are presented in Table 4. 
Table 4 Zeta potential of solid particles and mean aggregate sizes for the examined suspensions without and with PAA

\begin{tabular}{ccc}
\hline Sample & $\begin{array}{c}\text { Zeta potential } \\
{[\mathrm{mV}]}\end{array}$ & $\begin{array}{c}\text { Diameter }[\mu \mathrm{m}] \\
\text { (zetasizer) }\end{array}$ \\
\hline $\mathrm{SiO}_{2}-\mathrm{NaCl}$ & -10.7 & 0.28 \\
$\mathrm{SiO}_{2}-\mathrm{NaCl}-\mathrm{PAA}$ & -39.9 & 0.47 \\
$\mathrm{HoYbSi}_{-} \mathrm{NaCl}$ & -16.7 & 0.52 \\
$\mathrm{HoYbSi1}-\mathrm{NaCl}-\mathrm{PAA}$ & -48.4 & 0.66 \\
$\mathrm{HoYbSi2}-\mathrm{NaCl}$ & -29.3 & 0.65 \\
$\mathrm{HoYbSi2}-\mathrm{NaCl}-\mathrm{PAA}$ & -51.1 & 0.74 \\
$\mathrm{HoYbSi3}-\mathrm{NaCl}$ & -40.6 & 0.75 \\
$\mathrm{HoYbSi3}-\mathrm{NaCl}-\mathrm{PAA}$ & -65.0 & 0.88 \\
\hline
\end{tabular}

The smallest aggregates $(0.28 \mu \mathrm{m})$ are formed in the suspension containing initial silica particles, which was characterized by the highest stability. In such a case the electrostatic repulsion between negatively charged particles $(\zeta=-10.7 \mathrm{mV})$ assures a relatively stable system. Similar behaviour was observed previously and described in our paper (Wiśniewska et al. 2013a; Terpiłowski et al. 2015). On the other hand silica-supported holmium-ytterbium nanocomposites form considerably greater aggregates and their electrokinetic potential assumes more negative values in comparison to the initial silica suspension. The polymer addition influences minimally mean aggregate diameters but causes a significant increase in the absolute values of the electrokinetic potential. Despite this, the composite/PAA systems remain unstable. It should be noted that in colloidal systems containing solid particles covered with ionic polymer layers not only electric effects but also steric ones are important for final system stability. In such a case the effective suspension destabilization can take place (even at high values of electrokinetic potential). Rather slight changes in aggregate sizes in the polymer presence suggest that the system destabilization is primarily due to the high specific gravity of the nanocomposites, and to a lesser extent - due to the presence of PAA adsorption layers. Additionally, the relatively low molecular weight of PAA equal to $2000 \mathrm{Da}$, makes it insufficient for the formation of polymer bridges between the solid particles and the effective flocculation process (which would result in a significant increase in the size of the formed aggregates) (Wiśniewska et al. 2013b; Wiśniewska et al. 2014).

The rates of particle migration and their mean sizes in the examined systems obtained from turbidimetric data are placed in Table 5 and Figure 9.

Table 5 Rate of migration and mean aggregate sizes for the examined suspensions without and with PAA

\begin{tabular}{ccc}
\hline Sample & Rate of migration & Diameter $[\mu \mathrm{m}]$ \\
(turbiscan) \\
$\mathrm{SiO}_{2}-\mathrm{NaCl}$ & $2 \mu \mathrm{m} / \mathrm{min}]$ & 0.23 \\
$\mathrm{SiO}_{2}-\mathrm{NaCl}-\mathrm{PAA}$ & 2.78 & 0.52 \\
\hline
\end{tabular}




\begin{tabular}{ccc}
\hline HoYbSi1-NaCl & 11.22 & 0.46 \\
HoYbSi1-NaCl-PAA & 10.07 & 0.44 \\
HoYbSi2-NaCl & 12.84 & 0.49 \\
HoYbSi2-NaCl-PAA & 13.04 & 0.50 \\
HoYbSi3-NaCl & 12.69 & 0.49 \\
HoYbSi3-NaCl-PAA & 11.78 & 0.47 \\
\hline
\end{tabular}

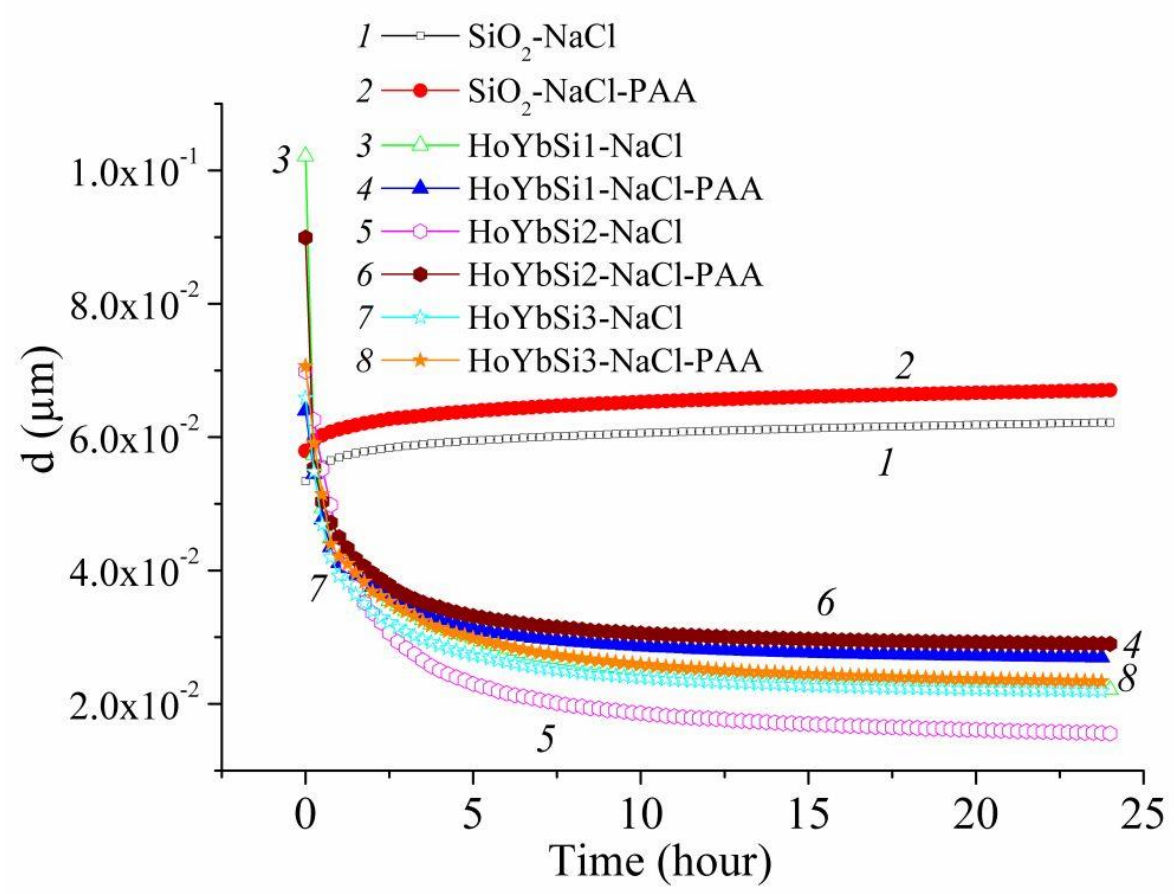

Fig. 9 Changes in aggregate diameters (d) as a function of time (during the 24 hours of stability measurement) for all examined suspensions

The dynamic of particle migration is directly connected with the system stability conditions. The higher the TSI coefficients are, the higher values of solid particle migration rates are observed. Moreover, the mean aggregate diameters obtained from turbidimetric data (Table 5) are noticeably lower than those obtained from electrokinetic data (Table 4), although the trend of changes is similar. This difference can result from various phenomena and theories used for measurements and calculations applying by both methods.

\section{Conclusions}

Novel ternary $\mathrm{Ho}_{2} \mathrm{O}_{3}-\mathrm{Yb}_{2} \mathrm{O}_{3} / \mathrm{SiO}_{2}$ nanocomposites were successfully prepared using a liquid-phase method and subjected to thermal treatment at $550{ }^{\circ} \mathrm{C}$. The initial $\mathrm{SiO}_{2}$ was used for comparison purposes. The XRD patterns show that the samples HoYbSi1 $\left(\mathrm{Ho}_{2} \mathrm{O}_{3}: \mathrm{Yb}_{2} \mathrm{O}_{3}: \mathrm{SiO}_{2}=0.5: 10: 89.5\right.$, wt. \%), HoYbSi2 $\left(\mathrm{Ho}_{2} \mathrm{O}_{3}: \mathrm{Yb}_{2} \mathrm{O}_{3}: \mathrm{SiO}_{2}=1: 10: 89\right.$, wt. \%) and $\mathrm{HoYbSi} 3\left(\mathrm{Ho}_{2} \mathrm{O}_{3}: \mathrm{Yb}_{2} \mathrm{O}_{3}: \mathrm{SiO}_{2}=2: 10: 88\right.$, wt. \%) calcined at $550{ }^{\circ} \mathrm{C}$ are amorphous in nature. FTIR results indicate that the coverage of the surface of fumed silica 
with $\mathrm{Ho}_{2} \mathrm{O}_{3}-\mathrm{Yb}_{2} \mathrm{O}_{3}$ oxides is partial since a fraction of free surface silanols is observed. It was shown that the nanocomposites have a high specific surface area $\left(200-212 \mathrm{~m}^{2} / \mathrm{g}\right)$, but slightly less than the $\mathrm{S}_{\mathrm{BET}}$ of

the initial silica $\left(256 \mathrm{~m}^{2} / \mathrm{g}\right)$. The IPSD functions indicate that the textural characteristics change after the modification of the silica by $\mathrm{Ho}$ and $\mathrm{Yb}$ oxides. The existence of predominantly mesoporosity of aggregates for initial silica and predominantly meso/macroporosity for $\mathrm{Ho}_{2} \mathrm{O}_{3}-\mathrm{Yb}_{2} \mathrm{O}_{3} / \mathrm{SiO}_{2}$ nanocomposites was found. The SEM and TEM results confirm the formation of aggregates of spherical structure with almost uniform distribution. The particle size distributions for all triple nanooxides in the aqueous suspensions are polymodal with characteristic PSD peaks while for individual silica it is monomodal. Silica modification with $\mathrm{Ho}_{2} \mathrm{O}_{3}-\mathrm{Yb}_{2} \mathrm{O}_{3}$ significantly changes the zeta potential and mean aggregate sizes of the examined suspensions without and with PAA. The turbidimetric results as a form of transmission and backscattering curves, as well as calculated stability parameters (TSI, aggregate diameter, rate of migration) indicate that initial silica suspension was characterized by the highest stability in comparison to nanocomposites HoYbSi1-3. Moreover, the addition of anionic polymer minimally influences the stability conditions of the studies systems. The prepared nanocomposites are promising materials for application in optoelectronic areas.

Acknowledgements The authors acknowledge financial support by the International Visegrad Fund supporting the study stay of Dr. I. Sulym (Contract number 51910525) at the UMCS in 2019-2020.

Author contributions IS designed the whole work, carried out the synthesis and characterization of nanocomposites by FTIR method and measurements of PSD for samples. IS calculated the textural parameters for initial silica and nanocomposites using a self-consistent regularization procedure. MW and KT performed the electrokinetic and stability measurements of samples. MB carried out XRD studies of nanocomposites. LS performed TEM studies and size analysis of nanocomposites using SEM/TEM images. DS and ADM participated in the measurement of SEM, XRF and low temperature nitrogen adsorptiondesorption technique for nanocomposites. IS and MW analyzed all data and wrote the original draft of the manuscript. MB and ADM performed the final reviewing and editing of the manuscript. All authors read and approved the final manuscript.

\section{Compliance with ethical standards}

Conflict of interest On behalf of all authors, I state that there is no conflict of interest.

\section{References}

Adachi G, Imanaka N (1998) The binary rare earth oxides. Chem Rev 98:1479-1514. https://doi.org/10.1021/cr940055h

Adachi G, Imanaka N, Tamura S (2001) Rare earth ion conduction in solids. J Alloys Compd 323324:534-539. https://doi.org/10.1016/S0925-8388(01)01138-0 
Bunjerd J, Sujittra K, Piyasan P (2007) Study of cobalt dispersion onto the mixed nano- $\mathrm{SiO}_{2}-\mathrm{ZrO}_{2}$ supports and its application as a catalytic phase. Mater Chem Phys 105:14-19.

\section{https://doi.org/10.1016/j.matchemphys.2007.04.015}

Chibowski S, Wiśniewska M, Marczewski AW, Pikus S (2003) Application of the SAXS and viscometry for determination of the thickness of adsorbed polymer layers at the $\mathrm{ZrO}_{2}$-polymer solution interface. J Colloid Interf Sci. 267:1-8. https://doi.org/10.1016/S0021-9797(03)00698-2

Dooley KM, Kalakota V, Adusumilli S (2011) High-temperature desulfurization of gasifier effluents with rare earth and rare earth/transition metal oxides. Energ Fuel 25:1213-1220. https://doi.org/10.1021/ef101487v

Gao J, Guo J, Liang D, Hou Z, Fei J, Zheng X (2008) Production of Syngas via Autothermal Reforming of Methane in a Fluidized-bed Reactor over the Combined $\mathrm{CeO}_{2}-\mathrm{ZrO}_{2} / \mathrm{SiO}_{2}$ Supported Ni Catalysts. Int J Hydrog Energy 33: 5493-5500. https://doi.org/10.1016/j.ijhydene.2008.07.040

Ghanashyam KM, Rajendran M, Pyke DR, Bhattachary AK (1999) Spectral emissivity of ytterbium oxide-based materials for application as selective emitters in thermophotovoltaic devices. Sol Energy Mater Sol Cells 59:337-348. https://doi.org/10.1016/S0927-0248(99)00049-5

Goncharuk O, Shipul O, Dyachenko A, Ischenko O, Andriyko L, Marynin A, Pakhlov E, Oranska O, Borysenko M (2019) Silica-supported Ni and Co nanooxides: Colloidal properties and interactions with polar and nonpolar liquids. J mol liq 285:397-402. https://doi.org/10.1016/j.molliq.2019.04.127

Gregg SJ, Sing KSW (1982) Adsorption, Surface Area and Porosity. Academic Press, London

Gun'ko VM, Leboda R, Skubiszewska-Zieba J (2009) Heating effects on morphological and textural characteristics of individual and composite nanooxides. Adsorption 15:89-98. https://doi.org/10.1007/s10450-009-9160-2

Gun'ko VM (2014) Composite materials: Textural characteristics. Appl Surf Sci 307:444-454. https://doi.org/10.1016/j.apsusc.2014.04.055

Guo Z, Liu A, Meng Y, Fan C, Shin B, Liu G, Shan F (2017) Solution-processed ytterbium oxide dielectrics for low-voltage thin-film transistors and inverters. Ceram Int 43:15194-15200. https://doi.org/10.1016/j.ceramint.2017.08.052

Haumesser P-H, Gaume R, Viana B, Vivien D (2002) Determination of laser parameters of ytterbiumdoped oxide crystalline materials. J Opt Soc Am B 19:102365-2375. https://doi.org/10.1364/JOSAB.19.002365

Hunter RJ (1981) Zeta Potential in Colloid Science. Academic Press, New York Jacquelyn GB, Laura JB (2014) Microbiology: Principles and Explorations. 9th Edition, Wiley Joung D, Singh V, Park S, Schulte A, Seal S, Khondaker SI (2011) Anchoring Ceria Nanoparticles on Reduced Graphene Oxide and Their Electronic Transport Properties. J Phys Chem C 115:2449424500. https://doi.org/10.1021/jp206485v 
Kapridaki C, Maravelaki-Kalaitzaki P (2013) $\mathrm{TiO}_{2}-\mathrm{SiO}_{2}-\mathrm{PDMS}$ nano-composite hydrophobic coating with self-cleaning properties for marble protection. Prog Org Coat 76:400-410.

\section{https://doi.org/10.1016/j.porgcoat.2012.10.006}

Magdalane CM, Kaviyarasu K, Judith Vijaya J, Siddhardha B, Jeyaraj B (2017) Facile synthesis of heterostructured cerium oxide/yttrium oxide nanocomposite in UV light induced photocatalytic degradation and catalytic reduction: synergistic effect of antimicrobial studies. J Photochem Photobiol B 173:23-34. https://doi.org/10.1016/j.jphotobiol.2017.05.024

Magdalane CM, Kaviyarasu K, Raja A, Arularasu MV, Mola GT, Isaev AB, Al-Dhabi NA, Arasu MV, Jeyaraj B, Kennedy J, Maaza M (2018) Photocatalytic decomposition effect of erbium doped cerium oxide nanostructures driven by visible light irradiation: investigation of cytotoxicity, antibacterial growth inhibition using catalyst. J Photochem. Photobiol B Biol 185:275-282. https://doi.org/10.1016/j.jphotobiol.2018.06.011

Maggi R, Martens JA, Poncelet G, Grange P, Jacobs PA, Delmon B (1998) (ed) Preparation of catalysts VII. Elsevier, New York

Mekhemer GAH (2004) Surface acid-base properties of holmium oxide catalyst: in situ infrared spectroscopy. Appl Catal A-Gen 275:1-7. https://doi.org/10.1016/j.apcata.2004.05.036

Munawar T, Yasmeen S, Hasan M, Mahmood K, Hussain A, Ali A, Arshad MI, Iqbal F (2020) Novel triphase heterostructured $\mathrm{ZnO}-\mathrm{Yb}_{2} \mathrm{O}_{3}-\mathrm{Pr}_{2} \mathrm{O}_{3}$ nanocomposite; structural, optical, photocatalytic and antibacterial studies. Ceram Int 46:11101-11114. https://doi.org/10.1016/j.ceramint.2020.01.130

Parida SK, Dash S, Patel S, Mishra BK (2006) Adsorption of organic molecules on silica surface. Adv Colloid Interf Sci 121:77-110. https://doi.org/10.1016/j.cis.2006.05.028

Park K, Ahn S, Lim SH, Jin MH, Song J, Yun SY, Kim HM, Kim GJ, Ok KM, Hong J (2016) Ytterbium oxide nanodots via block copolymer self-assembly and their efficacy to dye-sensitized solar cells. Appl Surf Sci. 364:573-578. https://doi.org/10.1016/j.apsusc.2015.12.077

Reddy BM, Saikia P, Bharali P, Katta L, Thrimurthulu G (2009) Highly dispersed ceria and ceria-zirconia nanocomposites over silica surface for catalytic applications. Catal. Today 141:109114. https://doi.org/10.1016/j.cattod.2008.05.008

Ren C, Qiu W, Chen Y (2013) Physicochemical properties and photocatalytic activity of the $\mathrm{TiO}_{2} / \mathrm{SiO}_{2}$ prepared by precipitation method. Sep Purif Technol 107:264-272. https://doi.org/10.1016/j.seppur.2013.01.037

Snabre P, Mills P (1994) Settling of a suspension of hard-spheres. Europhys Lett 25:651-656. https://doi.org/10.1209/0295-5075/25/9/003

Sulym I, Sternik D, Oleksenko L, Lutsenko L, Borysenko M, Derylo-Marczewska A (2016a) Highly dispersed silica-supported ceria-zirconia nanocomposites: Preparation and characterization. Surf Interfaces 5:8-14. https://doi.org/10.1016/j.surfin.2016.08.001 
Sulym I, Goncharuk O, Sternik D, Skwarek E, Derylo-Marczewska A, Janusz W, Gun'ko VM (2016b) Silica-Supported Titania-Zirconia Nanocomposites: Structural and Morphological Characteristics

Sulym I, Goncharuk O, Skwarek E, Sternik D, Borysenko M V, Derylo-Marczewska A, Wladyslaw J, Gun'ko VM (2015) Silica-supported ceria-zirconia and titania-zirconia nanocomposites: structural characteristics and electrosurface properties. Colloids Surf A Physicochem Eng Asp 482:631-638. https://doi.org/10.1016/j.colsurfa.2015.07.015

Terpiłowski K, Wiśniewska M, Zarko V (2015) Influence of solution pH, supporting electrolyte presence and solid content on the stability of aqueous nanosilica suspension. J Ind Eng Chem 30:71-76. https://doi.org/10.1016/j.jiec.2015.05.003

Vishwanathan V, Roh H-S, Kim J-W, Jun K-W (2004) Surface properties and catalytic activity of $\mathrm{TiO}_{2}-$ $\mathrm{ZrO}_{2}$ mixed oxides in dehydration of methanol to dimethyl ether. Catal Lett 96:23-28. https://doi.org/10.1023/B:CATL.0000029524.94392.9f

Wiśniewska M, Terpiłowski K, Chibowski S, Urban T, Zarko VI, Gun’ko VM (2013a) Stability of Colloidal Silica Modified by Macromolecular Polyacrylic Acid (PAA) - Application of

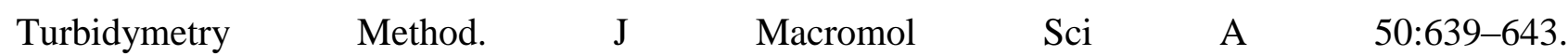
https://doi.org/10.1080/10601325.2013.784562

Wiśniewska M, Nosal-Wiercińska A, Dąbrowska I, Szewczuk-Karpisz K (2013b) Effect of the solid pore size on the structure of polymer film at the metal oxide/polyacrylic acid solution interface $\begin{array}{llll}\text { temperature } \quad \text { impact. Micropor } & \text { Mesopor }\end{array}$ https://doi.org/10.1016/j.micromeso.2013.03.032

Wiśniewska M, Urban T, Nosal-Wiercińska A, Zarko VI, Gun'ko VM (2014) Comparison of stability properties of poly(acrylic acid) adsorbed on the surface of silica, alumina and mixed silica-alumina nanoparticles - application of turbidimetry method. Cent Eur J Chem 12:476-479. https://doi.org/10.2478/s11532-013-0401-6

Zheng H, Xue H, Zhang Y, Shen Z (2002) A glucose biosensor based on microporous polyacrylonitrile synthesized by single rare-earth catalyst. Biosens Bioelectron 17:541-545. https://doi.org/10.1016/S0956-5663(02)00010-6

Zheng Y, Lü Q, Wang J, Zhang G, Gao Y, Liu Z (2014) Emission behaviors of $\mathrm{Yb}_{2} \mathrm{O}_{3}$ nanoparticles pumped by $980 \mathrm{~nm}$ laser at different power densities. Opt Laser Technol 63:39-44. http://dx.doi.org/10.1016/j.optlastec.2014.03.012

Zinatloo-Ajabshir S, Mortazavi-Derazkola S, Salavati-Niasari M (2017) Simple sonochemical synthesis of $\mathrm{Ho}_{2} \mathrm{O}_{3}-\mathrm{SiO}_{2}$ nanocomposites as an effective photocatalyst for degradation and removal of organic contaminant. Ultrason sonochem 39:452-460. https://doi.org/10.1016/j.ultsonch.2017.05.016 


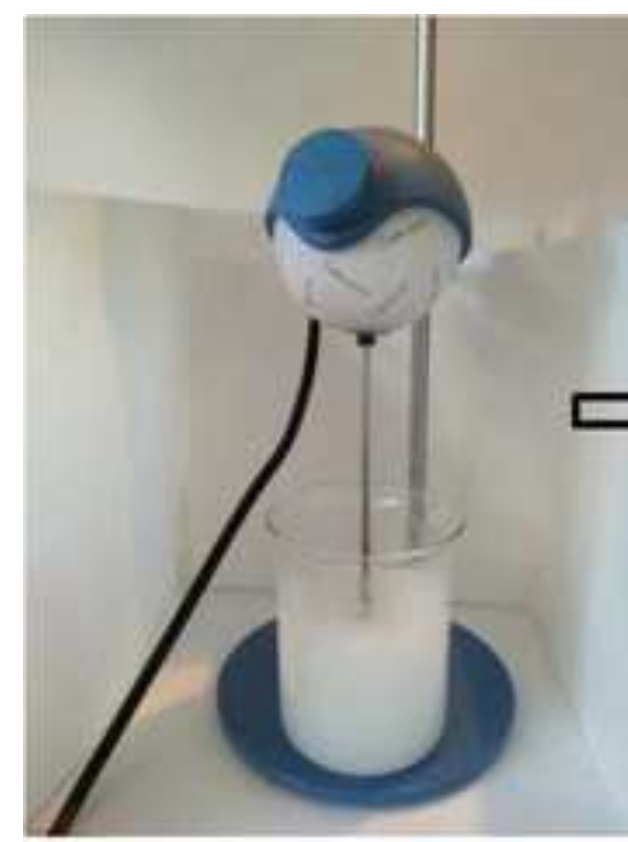

Stirring, $30 \mathrm{~min}$

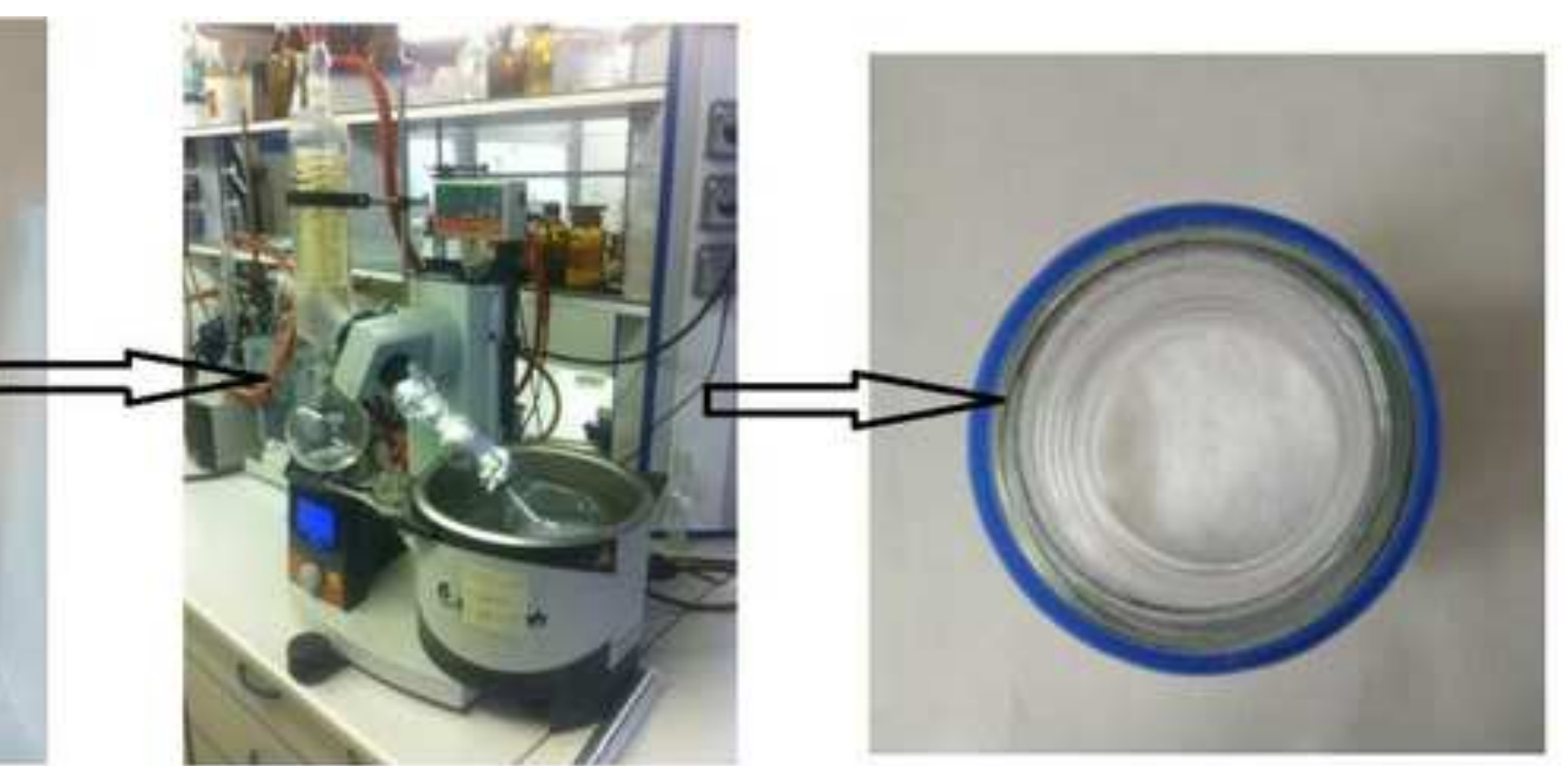

Rotary evaporation $\quad \mathrm{Ho}_{2} \mathrm{O}_{3}-\mathrm{Yb}_{2} \mathrm{O}_{3} / \mathrm{SiO}_{2}$ nanocomposite after calcination 


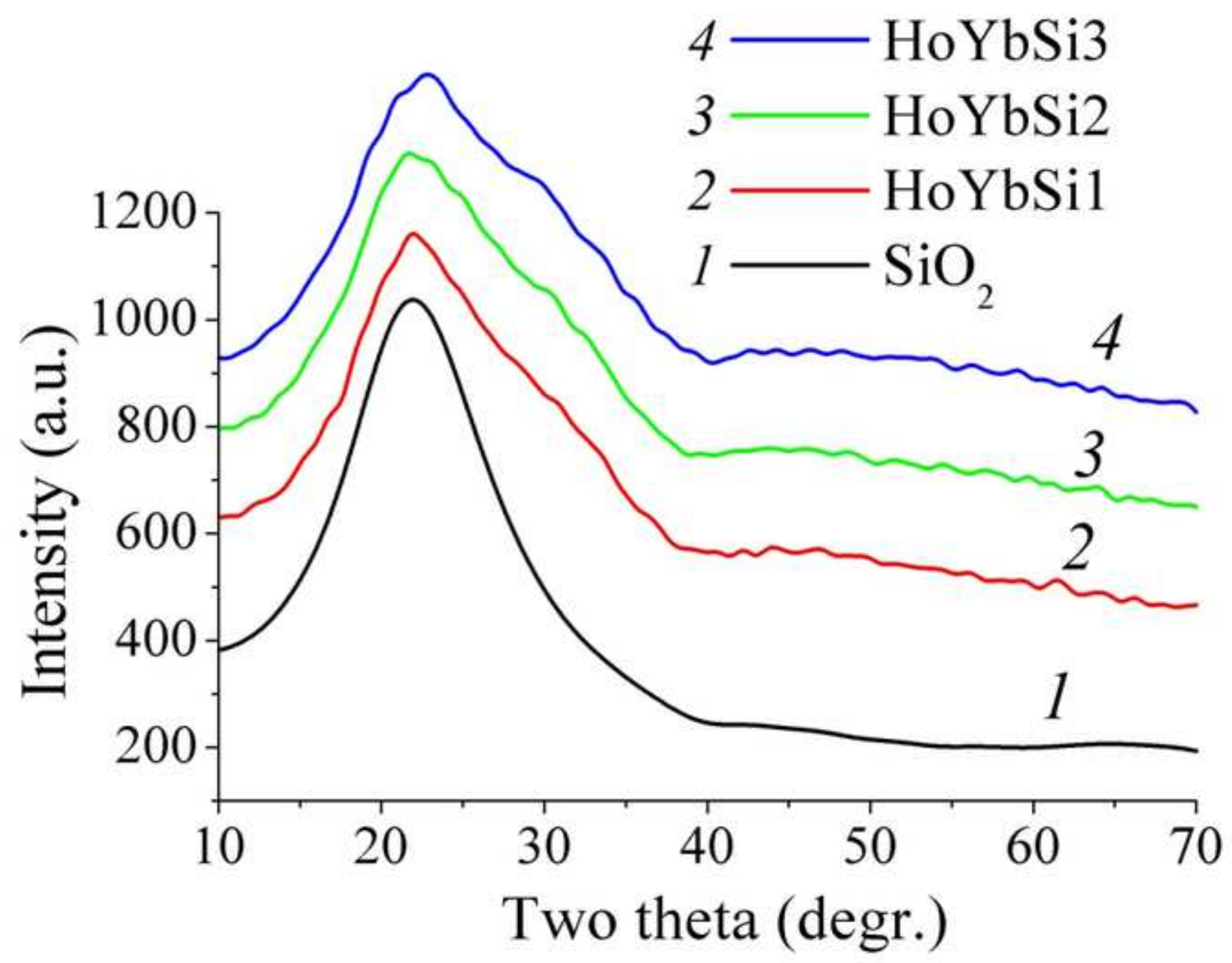



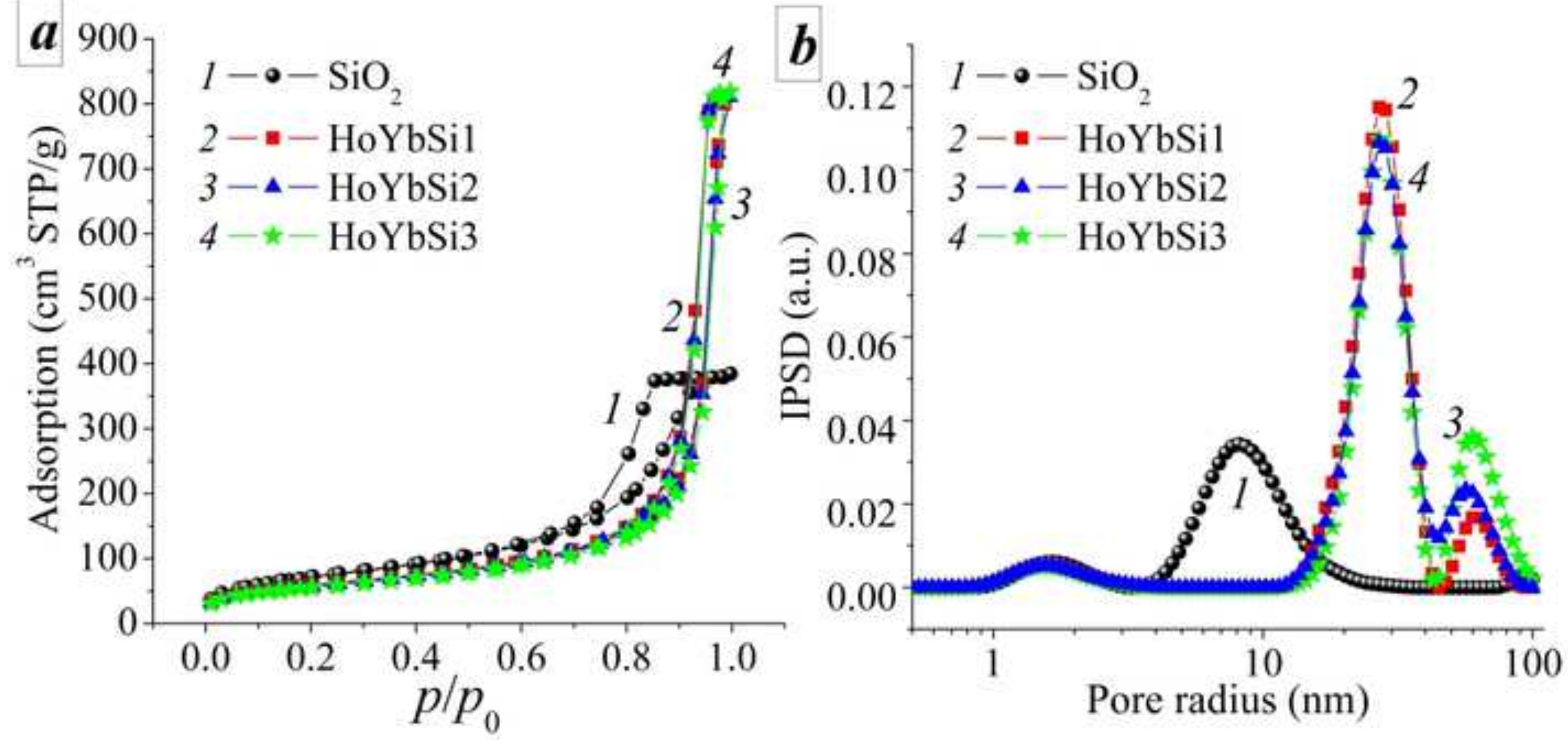


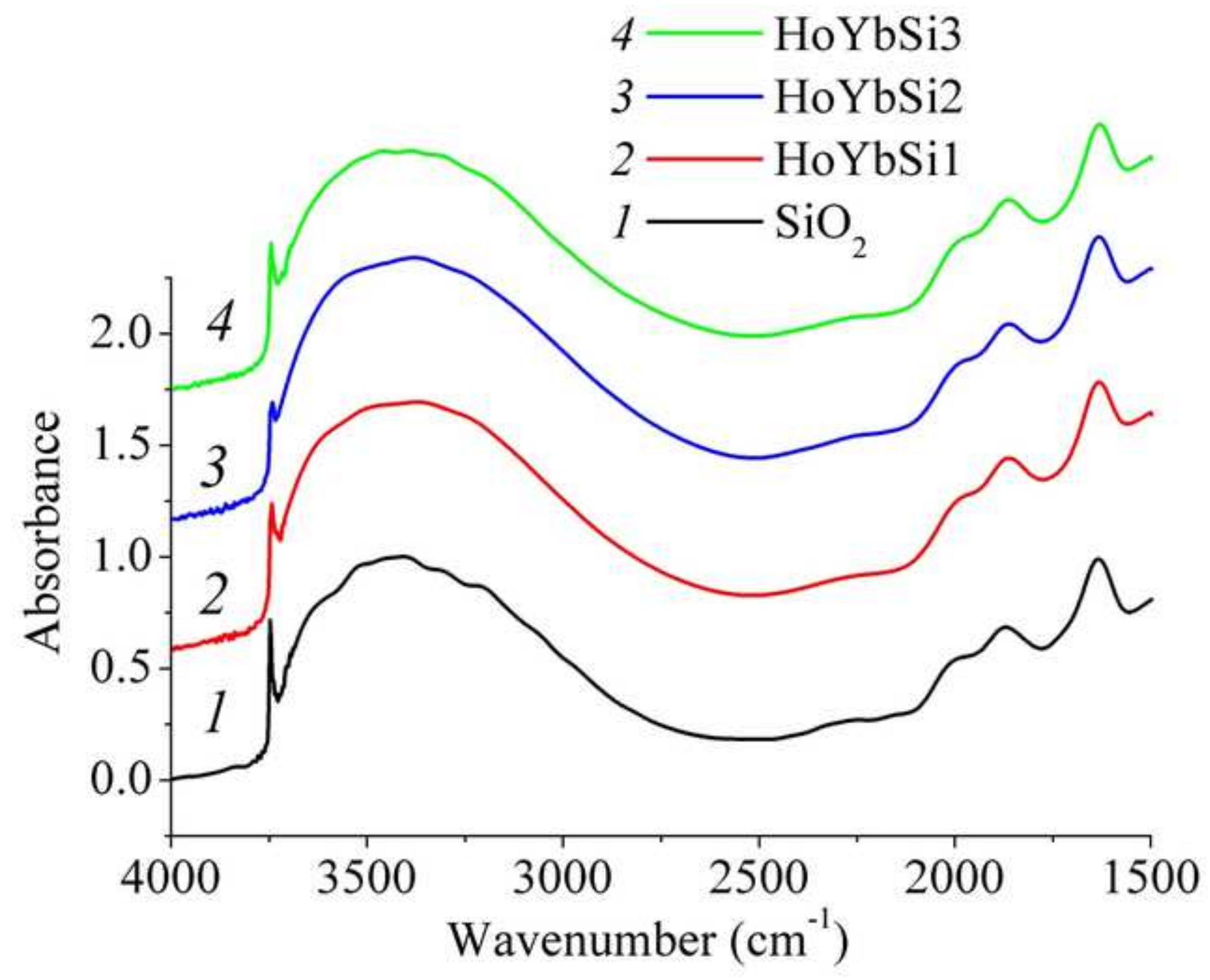



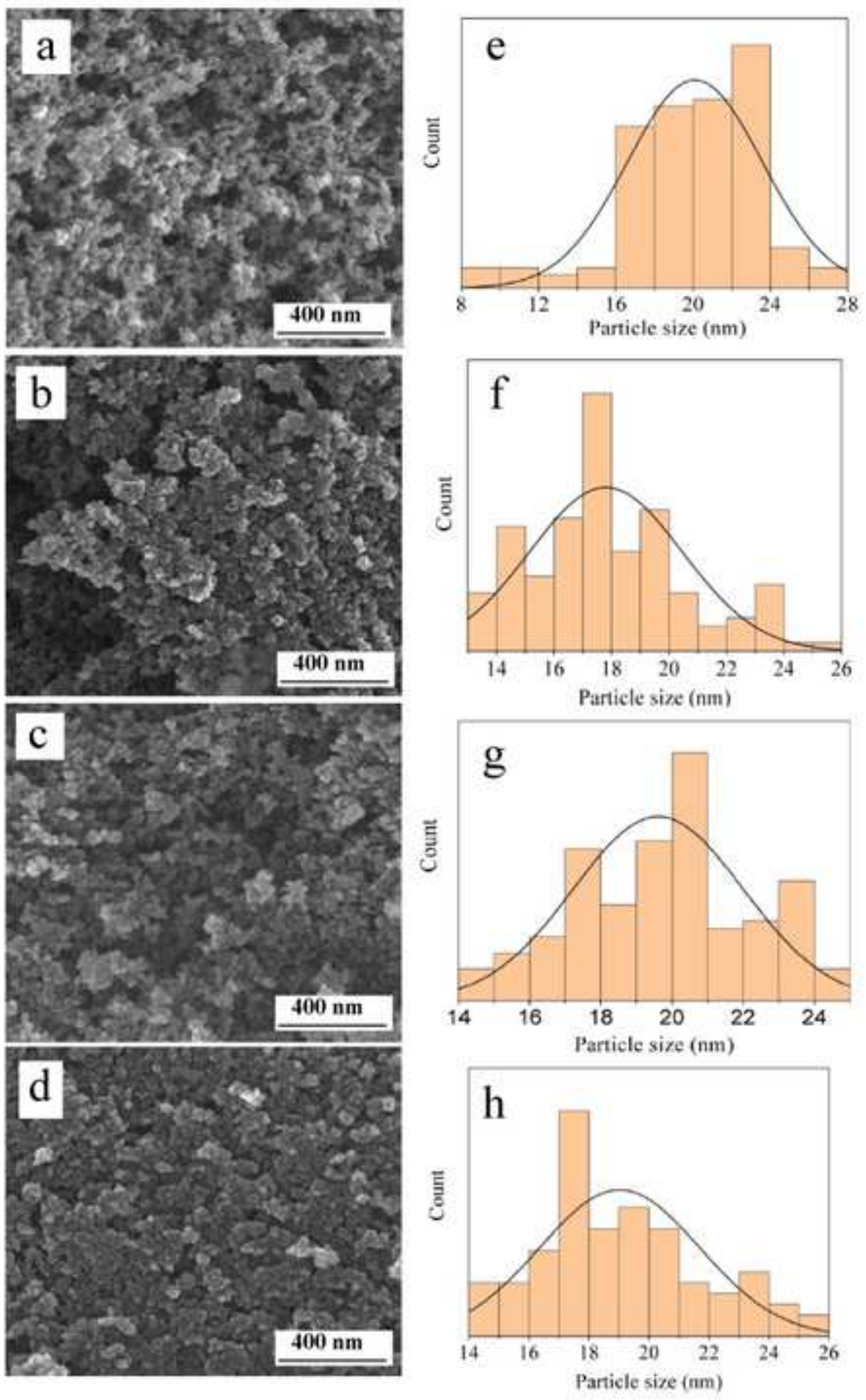

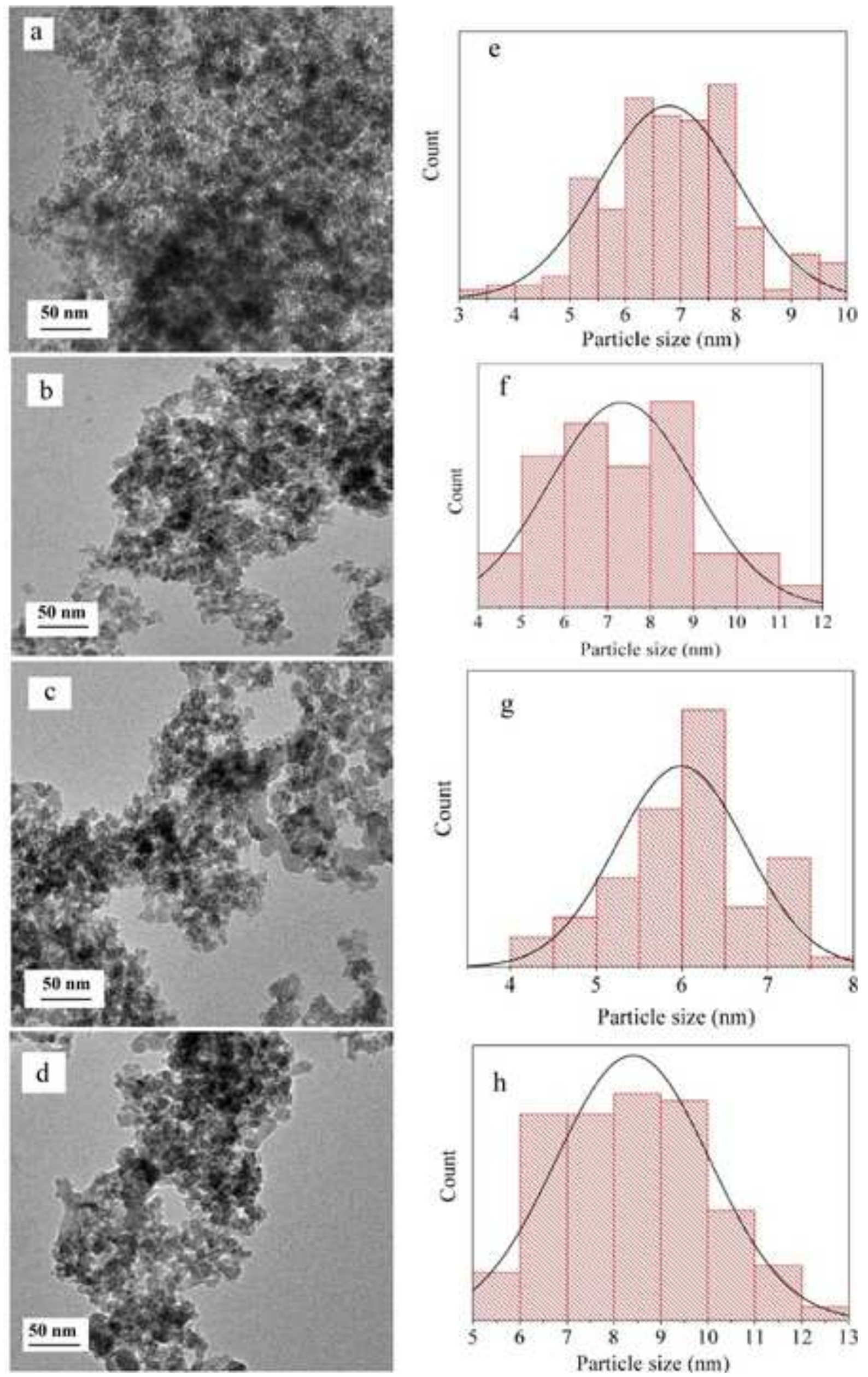

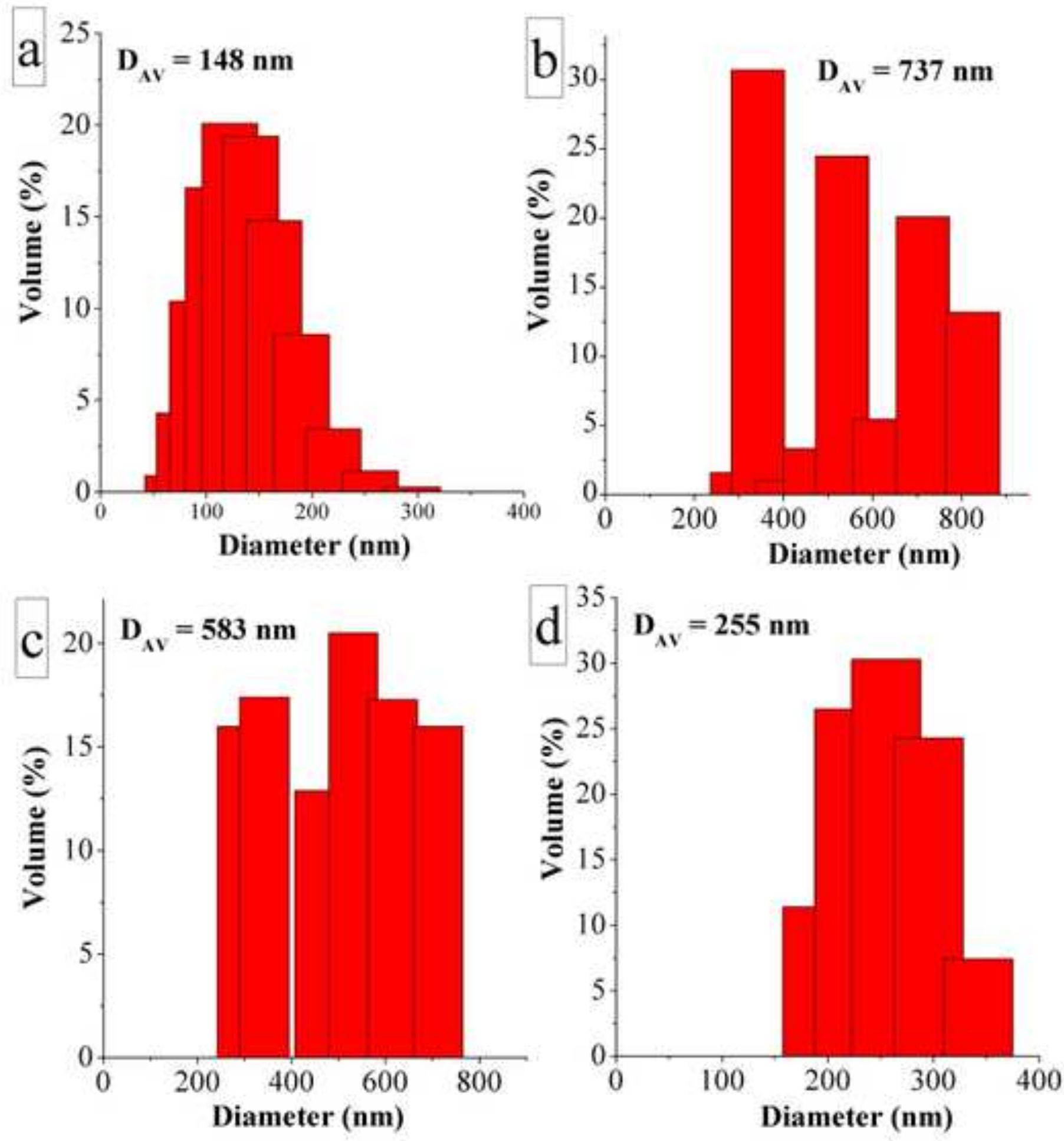

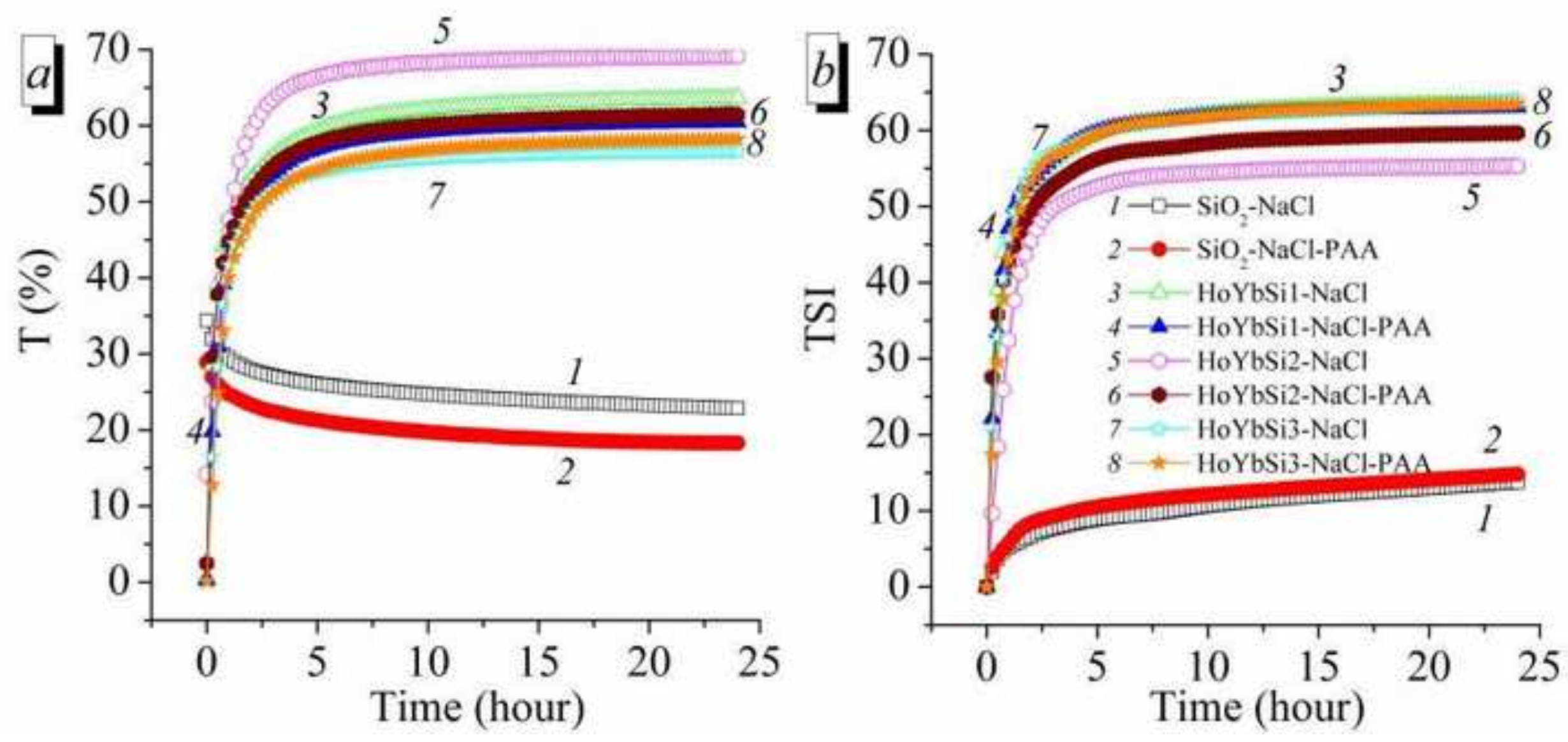


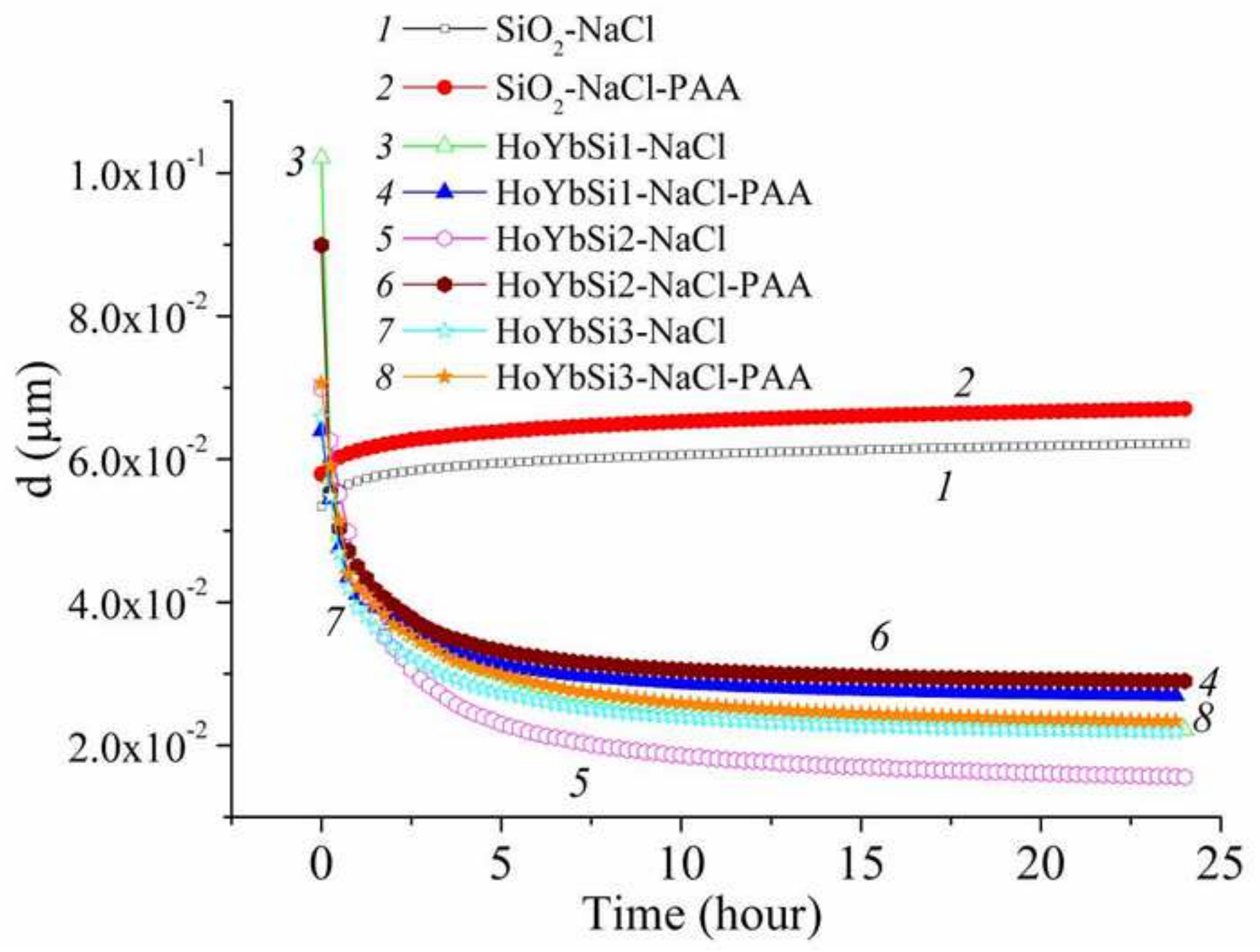

